Original article

\title{
Design, synthesis and structure-activity relationship of phthalimides endowed with dual antiproliferative and immunomodulatory activities
}

\author{
Marcos Veríssimo de Oliveira Cardoso ${ }^{\text {a, }}$, Diogo Rodrigo Magalhães Moreira ${ }^{\text {, }}$ \\ Gevanio Bezerra Oliveira Filho ${ }^{a}$, Suellen Melo Tiburcio Cavalcanti ${ }^{a}$, \\ Lucas Cunha Duarte Coelho ${ }^{a}$, José Wanderlan Pontes Espíndola ${ }^{a}$, Laura Rubio Gonzalez ${ }^{a}$, \\ Marcelo Montenegro Rabello a , Marcelo Zaldini Hernandes ${ }^{\text {a }}$, \\ Paulo Michel Pinheiro Ferreira b, Cláudia Pessoa ${ }^{c, d}$, Carlos Alberto de Simone ${ }^{\text {, }}$ \\ Elisalva Teixeira Guimarães ${ }^{\mathrm{f}, \mathrm{g}}$, Milena Botelho Pereira Soares ${ }^{\mathrm{g}}$, Ana Cristina Lima Leite ${ }^{\mathrm{a}}$ \\ a Departamento de Ciências Farmacêuticas, Centro de Ciências da Saúde, Universidade Federal de Pernambuco, 50740-520, Recife, PE, Brazil \\ ${ }^{\mathrm{b}}$ Departamento de Biofisica e Fisiologia, Programa de Pós-Graduação em Ciências Farmacêuticas, Universidade Federal do Piauí, 64049-550, Teresina, PI, \\ Brazil \\ ${ }^{\mathrm{c}}$ Departamento de Fisiologia e Farmacologia, Faculdade de Medicina, Universidade Federal do Ceará, 60430-270, Fortaleza, CE, Brazil \\ d Fundação Oswaldo Cruz, 60180-900, Fortaleza, CE, Brasil \\ e Departamento de Física e Informática, Instituto de Física, Universidade de São Paulo, 13560-970, São Carlos, SP, Brazil \\ ${ }^{\mathrm{f}}$ Departamento de Ciências da Vida, Universidade do Estado da Bahia, 41150-000, Salvador, BA, Brazil \\ ${ }^{\mathrm{g}}$ Hospital São Rafael, 41253-190, Salvador, BA, Brazil
}

\section{A R T I C L E I N F O}

\section{Article history:}

Received 11 November 2014

Received in revised form

15 April 2015

Accepted 18 April 2015

Available online 20 April 2015

Keywords:

Phthalimide

Thiosemicarbazone

Thiazole

Thiazolidinone

Antiproliferative

Immunosuppressive

\begin{abstract}
A B S T R A C T
The present work reports the synthesis and evaluation of the antitumour and immunomodulatory properties of new phthalimides derivatives designed to explore molecular hybridization and bioisosterism approaches between thalidomide, thiosemicarbazone, thiazolidinone and thiazole series. Twenty-seven new molecules were assessed for their immunosuppressive effect toward TNF $\alpha$, IFN $\gamma$, IL-2 and IL-6 production and antiproliferative activity. The best activity profile was observed for the (6a-f) series, which presents phthalyl and thiazolidinone groups.
\end{abstract}

๑) 2015 Elsevier Masson SAS. All rights reserved.

\section{Introduction}

Thalidomide appears to be a multi-target drug that impinges on a number of seemingly distinct cellular processes, including peptidase inhibition, glucosidase inhibition, androgen receptor antagonism and (cyclooxygenase) COX inhibition [1].

One of the most studied biological activities influenced by thalidomide is the inhibition of the expression of the pro-

\footnotetext{
* Corresponding author.

E-mail address: marcosvocardoso@gmail.com (M.V.O. Cardoso).
}

inflammatory cytokine tumour necrosis factor (TNF $\alpha$ ) [2]. TNF is a central regulator of the inflammatory cascade that controls many effector pathways as anti-angiogenic, anti-inflammatory and immunomodulatory molecule. The molecular mode of action of thalidomide on TNF $\alpha$ expression is thought to involve the inflammatory NFjB signalling pathway, specifically inhibiting the activity of the IjB kinase, IKKa [3].

Thalidomide is also known as an inhibitor of nuclear factor kappa B (NF- $\kappa$ B) activation [4-7]. NF- $\kappa$ B is a family of structurally related transcription factors that play a major role in inflammation and immune responses. Moreover, NF- $\kappa \mathrm{B}$ inhibits apoptosis, and 
induces proliferation and angiogenesis, suggesting that NF- $\mathrm{B}$ B has a pivotal role in oncogenesis and tumour progression [8,9].

Immunomodulatory drugs (IMiDs) are thalidomide derivatives with improved anti-tumour activity and safer toxicity profiles [10]. The two leading IMiD compounds, lenalidomide (CC-5013; IMiD3; Revlimid) and pomalidomide (CC-4047; IMiD1; Actimid), were the first drugs to enter into clinical trials for the treatment of multiple myeloma in 1999 [11] and are the subject of clinical evaluation in other haematological malignancies [12]. Studies on the structure-activity relationship (SAR) of the metabolites of thalidomide and its analogues have revealed that the phthalimide ring system is an essential pharmacophoric fragment [13].

In fact, substituted $\mathrm{N}$-phenylphthalimides are of high interest because they have been found to inhibit TNF $\alpha[1,14]$ and COX [1], and have tubulin binding properties [15]. With these properties in mind, phthalimide has usually been employed in the design of potential antiinflammatory [16], immunomodulatory [17-19], antiangiogenic [20-22] and antitumour [23-26] drug candidates. In this promising scenario, the strategy of molecular hybridization using phthalimide as a pharmacophoric fragment have figured prominently and led to many successful cases [14]. On the other hand, thiosemicarbazones are compounds of considerable interest because of their important chemical properties and potentially beneficial biological activities [27-30].

In general, the synthesis of thiosemicarbazone compounds presents low cost and high atom economy because all the atoms from the reagents (except the water liberated in the condensation) are present in the final molecule.

4-N-substituted thiosemicarbazones show remarkable activity in comparison with their unsubstituted counterparts. An enhanced inhibitory effect may be attributed to the increased lipophilicity that allows the molecules to easily cross the cell membrane. The 4$\mathrm{N}$ nitrogen of the thiosemicarbazone skeleton may contain: a) two hydrogen atoms (unsubstituted thiosemicarbazones); b) one hydrogen atom and one alkyl or aryl group and c) two alkyl or aryl groups or may be a part of a cyclic ring [31].

Bearing in mind the molecular pharmacophores outlined above and their structural requirements, some phthalimide derivatives were designed after exploring molecular hybridization and bioisosterism approaches between thalidomide, thiosemicarbazone, thiazolidinone and thiazole moieties (Fig. 1). These derivatives were synthesized by our group and based on the obtained biological data, and new SAR information was collected. Furthermore, a number of the derivatives exhibited potent in vivo activity against S-180 sarcoma cells that was comparable to that of the reference drug, thalidomide [32].

In a continuation of our work on the structure-activity relationship, twenty-seven new phthalimide derivatives were prepared to establish an appropriate SAR. Our design was based on the molecular hybridization of the phthalimide ring system with a thiosemicarbazone, thiazolidinone or thiazole subunit.

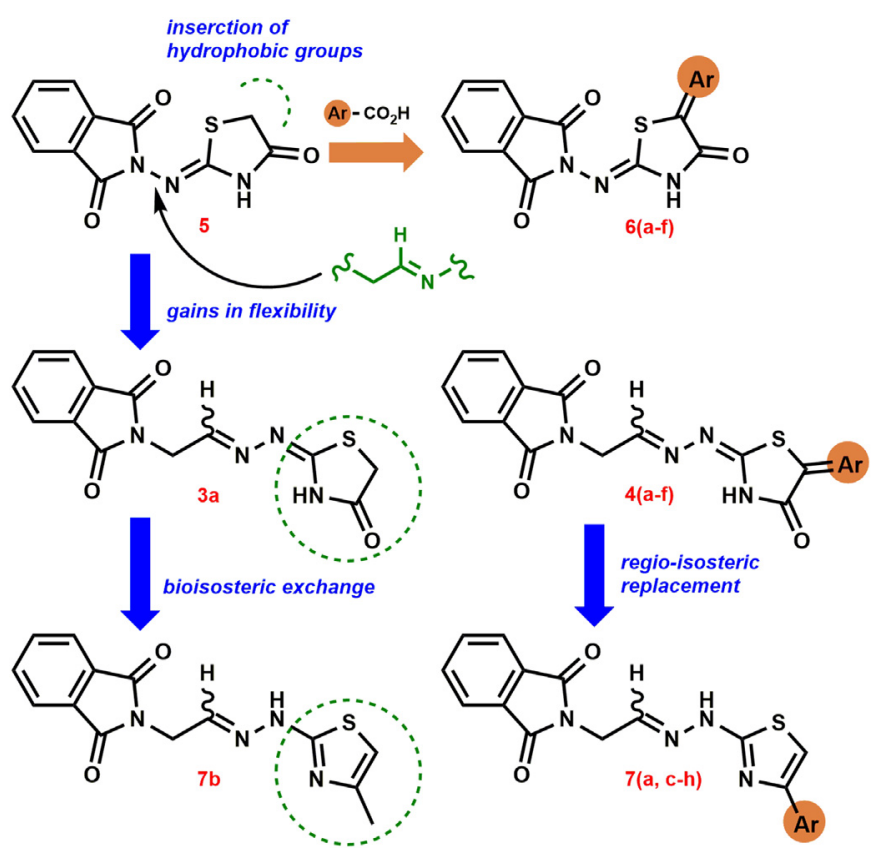

Fig. 2. Design concept of target compounds.

In the design concept, the 2-N and 4-N nitrogen of the thiosemicarbazone skeleton were then substituted by alkyl groups $(\mathbf{2 a}-\mathbf{c})$ to improve the lipophilicity. A set of compounds (3a-d, $4 \mathbf{a}-\mathbf{f}$ and $6 \mathbf{a}-\mathbf{f}$ ) bearing thiazolidinones was then synthesized by exploring bioisosteric relationship between thiazolidinones and thiosemicarbazones. Our approach also investigated the homologation between the phthalyl system and thiazolidinones ( $\mathbf{3 a}-\mathbf{d}$ and $\mathbf{4 a}-\mathbf{f})$ to investigate the influence of flexibility. Subsequently, a bioisosteric exchange between the thiazolidinone and thiazole nuclei was made, so that the 4-N nitrogen of the thiosemicarbazone skeleton was then converted to a thiazole ring that contained alkyl (7b) or phenyl groups (7a, 7c-h) (Fig. 2).

\section{Results and discussion}

\subsection{Chemistry}

The synthesis of N-phenyl-4-(thiazol-5-yl)pyrimidin-2-amine derivatives was adapted from the method described previously $[32,33]$ and is outlined in Scheme 1.

From the phthalic anhydride (1) obtained commercially, an acetal intermediate was first synthesized by imidification reaction with aminoacetaldehyde diethyl acetal reagent in the presence of DMAP. Then, this intermediate underwent acid hydrolysis to obtain the aldehyde intermediate, which was condensed with

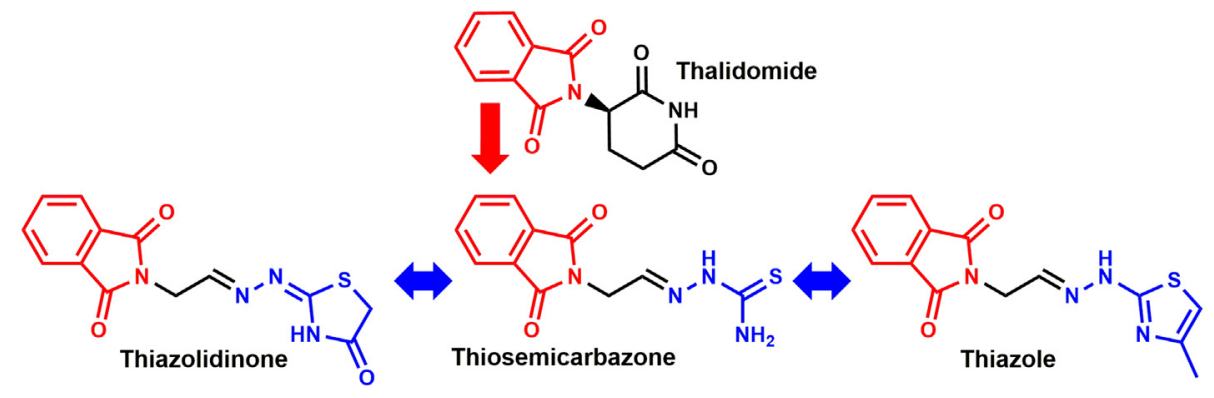

Fig. 1. Bioisosteric relationship between thalidomide and the proposed thiosemicarbazones, thiazolidinones and thiazoles. 
<smiles>[R2]NC(=S)N([R])N=CCN1C(=O)c2ccc(C(C)C)cc2C1=O</smiles>

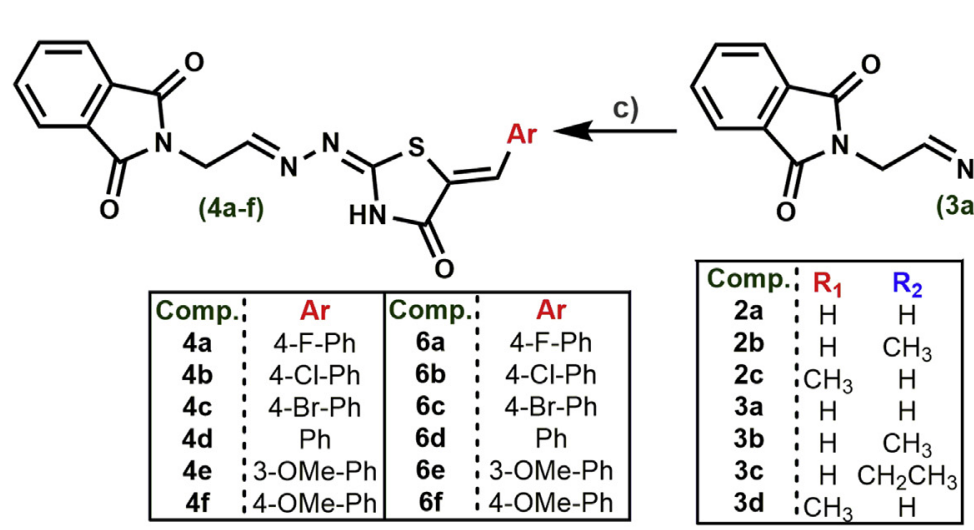

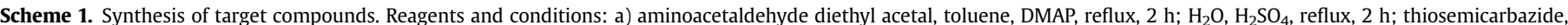

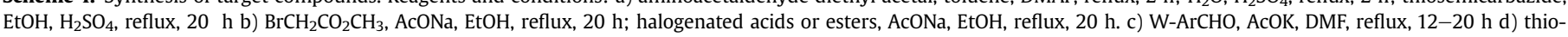
semicarbazide, DMAP, DMF, reflux, 1 h; $\mathrm{BrCH}_{2} \mathrm{CO}_{2} \mathrm{CH}_{3}$, AcONa, EtOH, reflux, 24 h. e) W-ArCHO, AcOK, DMF, reflux, 8-24 h.

thiosemicarbazide for the synthesis of phthalyl thiosemicarbazones $(\mathbf{2 a}-\mathbf{c})$, producing crystals in good yields and in a short reaction time. The thiazolidinone ( $\mathbf{3 a}-\mathbf{d})$ was synthesized by the cyclization of the thiosemicarbazones obtained with $\alpha$-halogenated acids or esters in AcONa. Finally, through the reaction between the thiazolidinone (3a) and different aryl-aldehydes in basic medium the benzylidyl-phthalyl-4-thiazolidinones $(\mathbf{4 a}-\mathbf{f})$ were obtained via Michael reaction.

In addition to the benzylidyl-phthalyl-4-thiazolidinones, $(\mathbf{6 a}-\mathbf{f})$, a homologous series to the compounds $(\mathbf{4 a}-\mathbf{f})$, was also synthesized. This synthesis occurred primarily through the reaction between the thiosemicarbazide and phthalic anhydride under acidic conditions, followed by cyclization of the thiosemicarbazone with methyl bromoacetate to obtain the intermediate $(\mathbf{5})$. Then, this intermediate was treated with the same aryl-aldehydes used in the synthesis of compounds $(\mathbf{4 a}-\mathbf{f})$.

The phthalyl-thiazoles $(\mathbf{7 a}-\mathbf{h})$ were produced through a cyclization reaction between the thiosemicarbazone (2a) and different substituted 2-bromoacetophenone in NaOAc (Scheme 2).

The chemical structure of these products was established using NMR $\left({ }^{1} \mathrm{H},{ }^{13} \mathrm{C}\right.$ and DEPT), IR spectral and elemental analysis (for $\mathrm{C}, \mathrm{H}$, $\mathrm{N}, \mathrm{S})$.

\subsection{X-ray analysis}

X-ray diffraction data collections were performed on an EnrafNonius Kappa-CCD diffractometer (95 mm CCD camera on $\kappa$ goniostat) using graphite monochromated $\mathrm{MoK} \alpha$ radiation $(0.71073 \AA)$, at room temperature. Data collections were carried out using the COLLECT software [34] up to $50^{\circ}$ in $2 \theta$. The final unit cell parameters were based on 6064 reflections for the (2a) compound and 3662 for the (2b) compound. Integration and scaling of the reflections, and correction for Lorentz and polarization effects were performed with the HKL DENZO-SCALEPACK system of programs

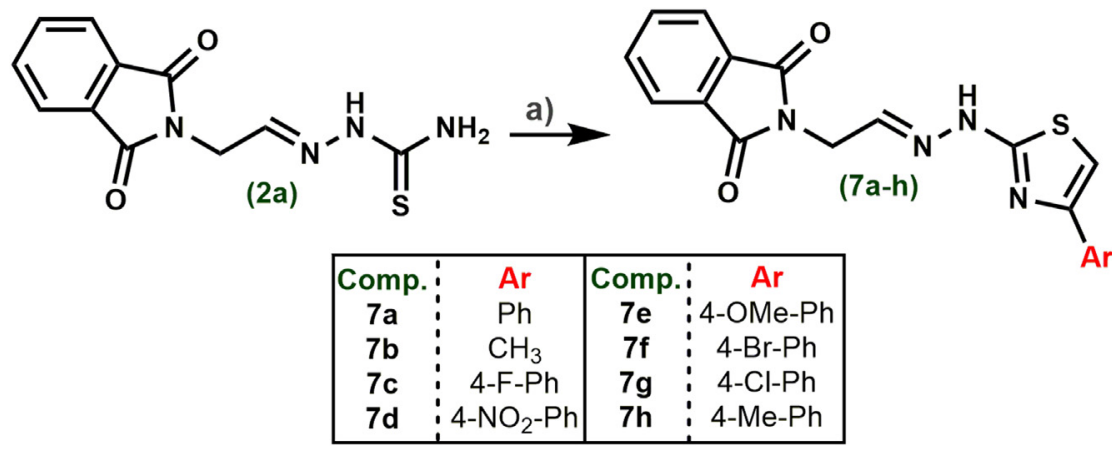

Scheme 2. Synthesis of target compounds. Reagents and conditions: a) substituted 2-bromoacetophenone, AcONa, ethanol, reflux, 4-24 h. 
[35]. The structures of compounds were solved by direct methods with SHELXS-97 [36]. The models were refined by full-matrix least squares on $\mathrm{F}^{2}$ using SHELXL-97 [36]. The program ORTEP-3 [37] was used for graphic representation, and the program WINGX [38] was used to prepare materials for publication. All $\mathrm{H}$ atoms were located by geometric considerations placed $(\mathrm{C}-\mathrm{H}=0.93-0.97 \AA$; $\mathrm{N}-\mathrm{H}=0.86 \AA)$ and refined as riding with $\mathrm{U}_{\text {iso }}(\mathrm{H})=1.5 \mathrm{U}_{\text {eq }}(\mathrm{C}-$ methyl) or $1.2 \mathrm{U}_{\mathrm{eq}}$ (other). An Ortep-3 diagram of the molecules is shown in Fig. 3, and Table 1 shows the main crystallographic parameters. All bond distances and angles, fractional coordinates, equivalent isotropic displacement parameters and other relevant information can be obtained free of charge from The Cambridge Crystallographic Data Centre via www.ccdc.cam.ac.uk/data request/cif under deposit numbers CCDC 972715 and CCDC 972716, respectively.

Bond lengths and angles are in good agreement with the expected values reported in the literature [39]. Compound (2a) crystallized with one solvent water molecule in the packing form OW-H1W $\cdots S^{\mathrm{i}}$ and OW-H2W $\cdots \mathrm{S}^{\mathrm{ii}}[\mathrm{i}=\mathrm{X}+1, \mathrm{y}, \mathrm{z}$; ii $=-\mathrm{x}+1,-\mathrm{y},-\mathrm{z}]$, and hydrogen-bonding interactions where: $\mathrm{H} 1 \mathrm{~W} \cdots \mathrm{S}^{\mathrm{i}}=2.387(2) \AA$ $\mathrm{OW}-\mathrm{H} 1 \mathrm{~W} \cdots \mathrm{S}^{\mathrm{i}}=169^{\circ}$ and $\mathrm{H} 2 \mathrm{~W} \cdots \mathrm{S}^{\mathrm{ii}}=2.549(2) \AA \AA$; OW$\mathrm{H} 2 \mathrm{~W} \cdots \mathrm{S}^{\mathrm{ii}}=158^{\circ}$.

\subsection{Pharmacological evaluation}

Once their structures were elucidated, all compounds were tested as immunomodulatory and anticancer agents. First, the potential immunological properties of the compounds were assessed by measuring the secretion of cytokines from the animal macrophages (TNF $\alpha$ and IL-6) and lymphocytes (IL-2 and IFN $\gamma$ ). Thalidomide (Thl) and dexamethasone (Dex) were used as controls.

$\mathrm{TNF} \alpha$, a highly pleiotropic cytokine produced primarily by monocytes and macrophages, plays a central role in the host's
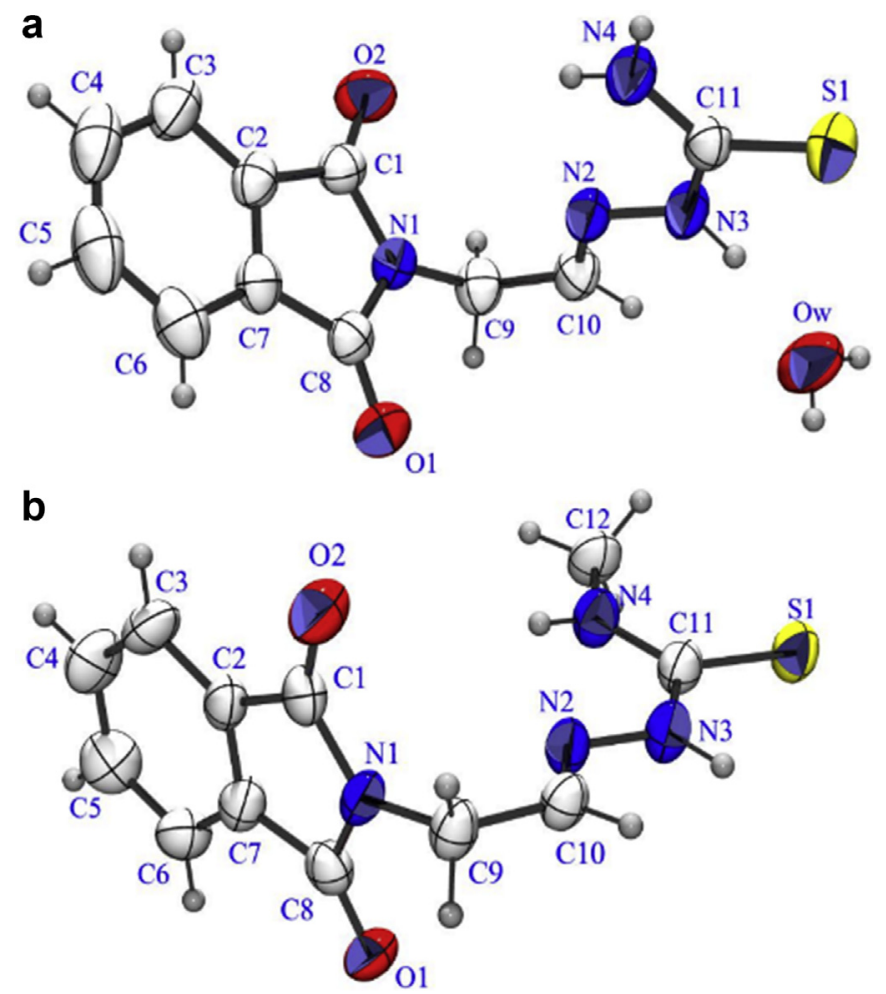

Fig. 3. ORTEP-3 projections of the compounds: (a) $\mathbf{2 a}$ and (b) $\mathbf{2} \mathbf{b}$, showing the atomnumbering and displacement ellipsoids at the $50 \%$ probability level.
Table 1

Main crystallographic parameters of compounds (2a) and (2b).

\begin{tabular}{|c|c|c|}
\hline & Compound (2a) & Compound (2b) \\
\hline Empirical formula & $\mathrm{C}_{11} \mathrm{H}_{10} \mathrm{~N}_{4} \mathrm{O}_{2} \mathrm{~S} \mathrm{H}_{2} \mathrm{O}$ & $\mathrm{C}_{12} \mathrm{H}_{10} \mathrm{~N}_{4} \mathrm{O}_{2} \mathrm{~S}$ \\
\hline Formula weight & 280.3 & 274.3 \\
\hline Crystal system & monoclinic & triclinic \\
\hline Space group & $\mathrm{P} 2 / \mathrm{c}$ & $\mathrm{P}-1$ \\
\hline $\mathrm{a}(\AA)$ & $5.4630(2)$ & $10.1470(7)$ \\
\hline b $(\AA)$ & $10.1120(4)$ & $9.9790(5)$ \\
\hline$c(\AA)$ & $23.9650(9)$ & $14.0120(8)$ \\
\hline$\alpha(\AA)$ & 90.0 & $77.804(3)$ \\
\hline$\beta(\AA)$ & $94.790(2)$ & $87.552(3)$ \\
\hline$\gamma(\AA)$ & 90.0 & $67.989(3)$ \\
\hline $\mathrm{V}\left(\AA^{3}\right)$ & $1319.25(2)$ & $1284.67(2)$ \\
\hline $\mathrm{Z}$ & 4 & 4 \\
\hline Radiation $(\lambda, \AA)$ & $\mathrm{M}_{\mathrm{o}} \mathrm{K}_{\alpha}(\lambda=0.71070 \AA)$ & $\mathrm{M}_{\mathrm{o}} \mathrm{K}_{\alpha}(\lambda=0.71070 \AA)$ \\
\hline$\mu\left(\mathrm{mm}^{-1}\right)$ & 0.255 & 0.255 \\
\hline Absorption correction & none & none \\
\hline Temp. (K) & $295(2)$ & $295(2)$ \\
\hline $\mathrm{D}_{\text {calc }}\left(\mathrm{Mg} \mathrm{m}^{-3}\right)$ & 1.41 & 1.42 \\
\hline Crystal dimensions (mm) & $0.32 \times 0.23 \times 0.07$ & $0.20 \times 0.19 \times 0.07$ \\
\hline$\theta$ range $\left(^{\circ}\right)$ & $3.3-27.5$ & $3.1-27.3$ \\
\hline Reflections collected $\left(\mathrm{R}_{\text {int }}\right)$ & $7398\left[\mathrm{R}_{\mathrm{int}}=0.046\right]$ & $13,033\left[\mathrm{R}_{\mathrm{int}}=0.07\right]$ \\
\hline Independent reflections & 2877 & 5040 \\
\hline Data/parameters & $2254 / 184$ & $1880 / 343$ \\
\hline Goodness-of-fit on $\mathrm{F}^{2}$ & 1.038 & 0.937 \\
\hline Final $\mathrm{R}$ indices $(\mathrm{I}>2 \sigma(\mathrm{I}))$ & $\mathrm{R} 1=0.041, \mathrm{wR} 2=0.108$ & $\begin{array}{l}\mathrm{R} 1=0.048 \\
\mathrm{wR} 2=0.124\end{array}$ \\
\hline $\mathrm{R}$ indices (all data) & $\mathrm{R} 1=0.055, \mathrm{wR} 2=0.121$ & $\begin{array}{l}\mathrm{R} 1=0.134 \\
\mathrm{wR} 2=0.169\end{array}$ \\
\hline
\end{tabular}

protective immune response to bacterial and viral infections $[40,41]$. However, it may also play a role in the pathogenesis of disease. Additionally, elevated levels of TNF $\alpha$ have been associated with fevers, malaise and weight loss that occur with chronic infections [42]. Otherwise, reductions in TNF $\alpha$ levels have been linked with an improvement in clinical symptoms in a number of disease states [43-45]. Immune stimulation with LPS was suitable for analysing TNF $\alpha$ production, and it was observed that among the 27 tested compounds, only four did not affect TNF $\alpha$ production at all (compounds $(\mathbf{4 b}-\mathbf{d})$ and $(\mathbf{7 e}))$. The inhibition profiles were observed for both concentrations tested ( 1 and $10 \mu \mathrm{g} / \mathrm{mL}$ ); however, a better inhibition profile was observed at $10 \mu \mathrm{g} / \mathrm{mL}$. Compounds (3a), (4a), (4e), (4f), (6e-f), (7a) and (7d) showed average \% inhibition cytokine between 52 and 73\%. At the same concentration, thalidomide did not have an inhibitory profile (Fig. 4).

When observing the thiazolidinone group, series 6 , showed better inhibition rates than did series 4 , which contains a space group between phthalyl and thiazolidinone ring. Phthalyl thiosemicarbazones (series 2 ) showed only moderate inhibitory activity.

IL-2 is instrumental in the body's natural response to microbial infection and is normally produced by TH1 cells [46]. Levels of this cytokine were significantly inhibited by compound (2c), (4a), (6a) and (6e) (45-72\% range). We found that, among the twenty-seven synthetic derivatives, compounds (4a) and (6e) displayed the strongest ability to inhibit IL-2 secretion. Compounds (4b-d), (4f), $(\mathbf{6 b}-\mathbf{d}),(\mathbf{7 d})$ and (7f) showed only a modest inhibition of IL-2 (Fig. 5). It is worth mentioning that the inhibitory ability was revealed only at a concentration of $1 \mu \mathrm{g} / \mathrm{mL}$.

For IL-2 cytokine, the thiazole nucleus ( $7 \mathbf{a}-\mathbf{h}$ series) is inactive for both concentrations. The activity was observed only at $1 \mu \mathrm{g} / \mathrm{mL}$, and it seems that phthalyl thiazolidones at $1 \mu \mathrm{g} / \mathrm{mL}$ (series $\mathbf{4 a}-\mathbf{f}$ and $\mathbf{6 a}-\mathbf{f}$ ) are selective for the inhibition of IL-2. Among the thiazolidinone series, series $\mathbf{3 a}-\mathbf{d}$ was the only series that did not produce inhibition. The main difference in this series is the benzylidine substituent at $\mathrm{C} 5$ of series $(\mathbf{4 a}-\mathbf{f})$. Compounds $(\mathbf{4 a})$ and (6e) were comparable to dexamethasone at the same concentration. Once again, Thl was inactive at the same concentration. 


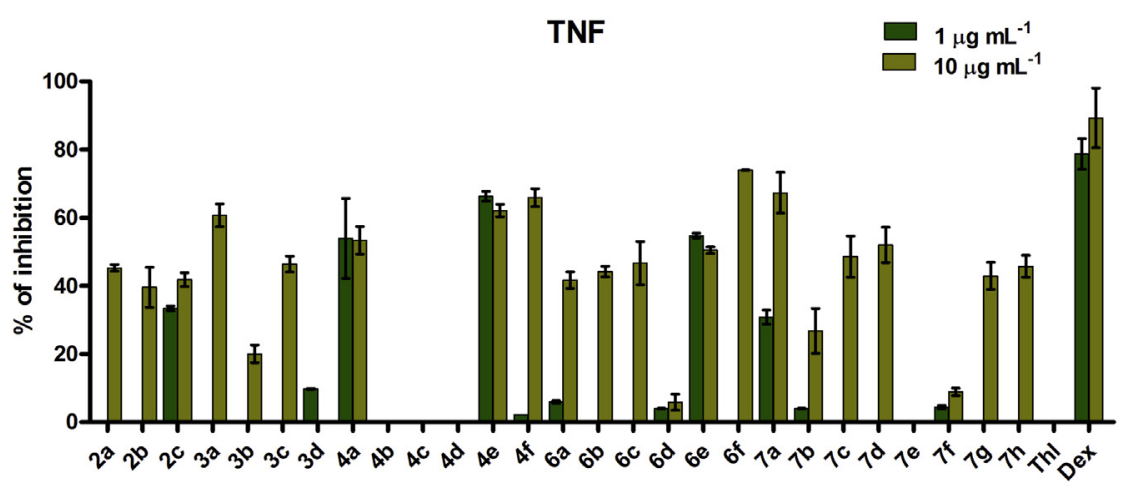

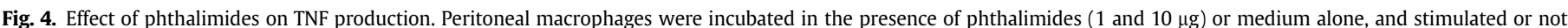

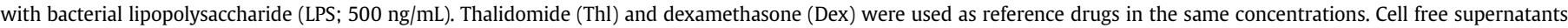

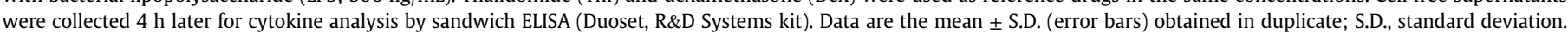

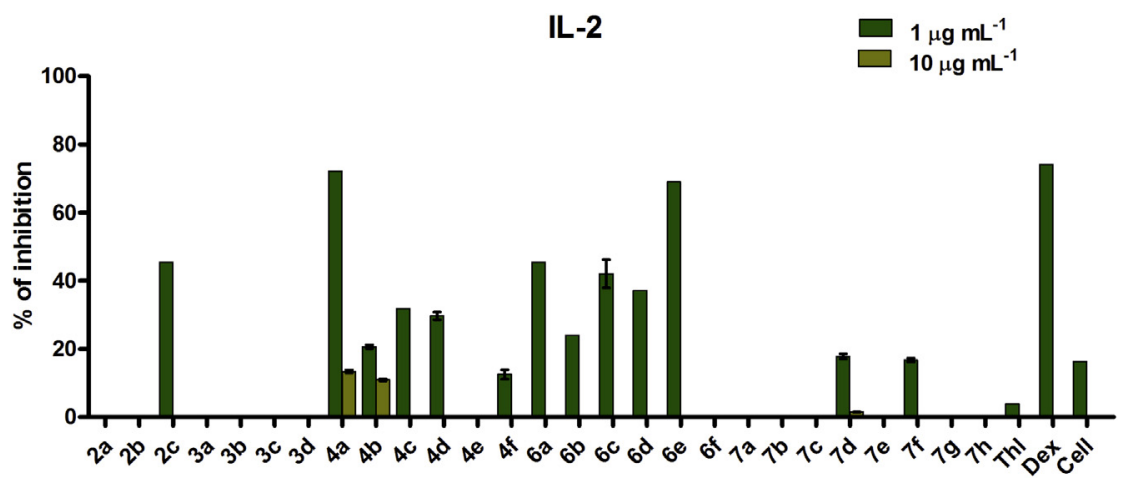

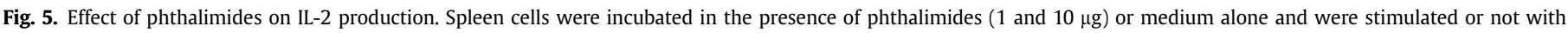

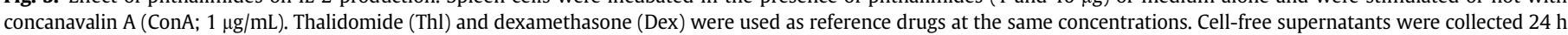
later for cytokine analysis by sandwich ELISA (Duoset, R\&D Systems kit). Data are the mean \pm S.D. (error bars) obtained in duplicate; S.D., standard deviation.

Interferon- $\gamma$ (IFN $\gamma$ ) is a cytokine secreted by lymphocytes that promotes innate immunity, i.e., natural killer (NK) cells, and cells that are components of the adaptive immune system (specific subsets of T cells) $[47,48]$. Furthermore, a role for IFN $\gamma$ in protection against tumour development has recently been identified [49]. The results have shown that endogenously produced IFN $\gamma$ is critical not only for the rejection of transplantable tumours but also to prevent primary tumour development [50]. The level of IFN $\gamma$ secretion was reduced by $95 \%$ (4b), 93\% (7b), 87\% (7d), 85\% (7h), $83 \%$ (2a), and $82 \%(3 \mathbf{b})$ at $1 \mathrm{mg} / \mathrm{mL}$ (Fig. 6). Derivative (4b) is the strongest inhibitor of IFN $\gamma$ secretion among the twenty-seven compounds and is comparable to dexamethasone (89\%) and Thl
(93\%). Both series representatives showed good inhibition activity at $1 \mu \mathrm{g} / \mathrm{mL}$, but no trend can be identified with regard to spacing groups or differences in ring structures (thiazolidinone versus thiazole).

IL-6, a pro-inflammatory cytokine, is secreted by the TH1 cells and macrophages and stimulates the immune response to trauma, especially burns or other tissue damage leading to inflammation. In terms of the host response to a foreign pathogen, IL-6 has been shown to provide resistance to mice against the bacterium, Streptococcus pneumoniae [51]. The effect of the tested compounds $(10 \mu \mathrm{g} / \mathrm{mL})$ on the secretion of this cytokine was only modest; the inhibition percentage did not reach 50\%. Compounds (2c), (6a-d),

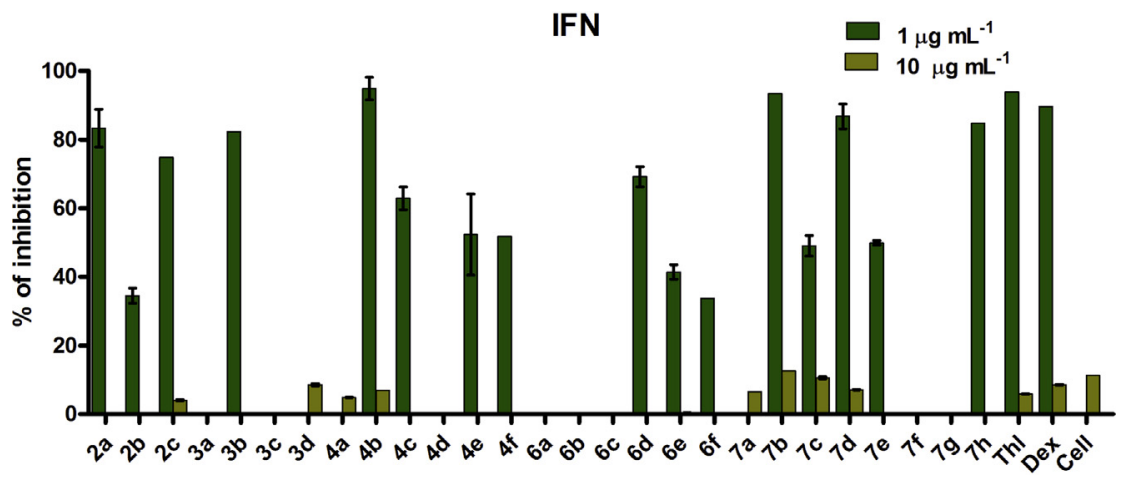

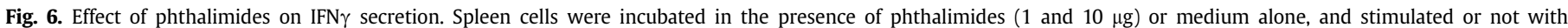

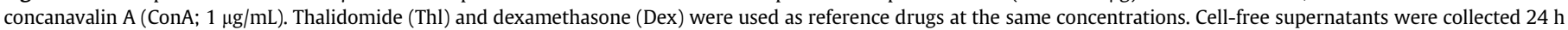
later for cytokine analysis by sandwich ELISA (Duoset, R\&D Systems kit). Data are the mean \pm S.D. (error bars) obtained in duplicate; S.D., standard deviation. 


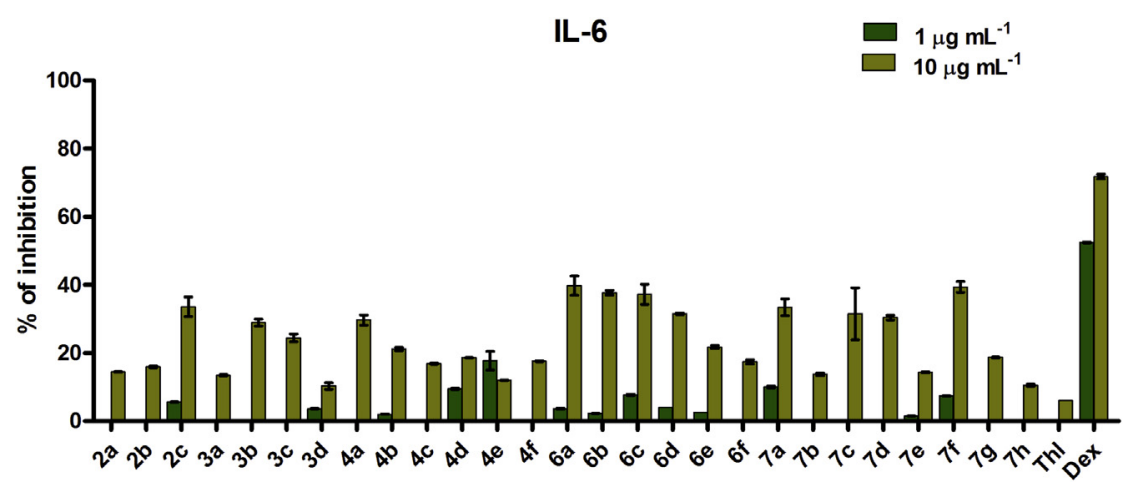

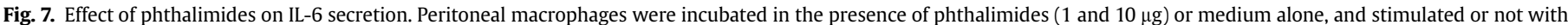

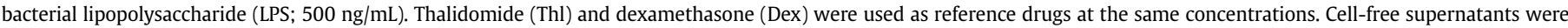
collected 4 h later for cytokine analysis by sandwich ELISA (Duoset, R\&D Systems kit). Data are the mean \pm S.D. (error bars) obtained in duplicate; S.D., standard deviation.

(7a), (7c), (7d) and (7f) showed inhibition in the range of 31-39\% (Fig. 7).

To investigate the anticancer properties of these compounds, these phthalimides were first evaluated against three tumour lines: MDA/MB-435 (melanoma), HCT-8 (colon) and SF-295 (nervous system).

Table 2 summarizes the cytotoxic action on tumour cells evaluated by MTT assay. Compounds from series $(\mathbf{6 a}-\mathbf{f})$ were the most potent, especially compounds $(\mathbf{6 b})$ and $(\mathbf{6 f})$, which revealed cell proliferation inhibition rates ranging from $87.0 \pm 11.1 \%$ (SF-295) to $100 \pm 1.1 \%(\mathrm{MDA} / \mathrm{MB}-435)$ and $\mathrm{IC}_{50}$ values of 7.5 and $5.3 \mu \mathrm{g} / \mathrm{mL}$ (SF295 ) and 5.8 and $5.2 \mu \mathrm{g} / \mathrm{mL}$ (HCT-8), respectively. Doxorubicin, used

Table 2

Screening of the in vitro cytotoxicity of 27 phthalimides derivatives on cancer cells at concentration of $50 \mu \mathrm{g} / \mathrm{mL}$ and lymphocytes at $5 \mu \mathrm{g} / \mathrm{mL}$. The cytotoxicity on both neoplasic and normal cells was determined by MTT assay.

\begin{tabular}{|c|c|c|c|c|c|}
\hline Sample & SF-295 & НCT-8 & MDA/MB-435 & LYMP (GI\%) & SD \\
\hline $2 a$ & NT & $30.1 \pm 0.8$ & $17.8 \pm 4.1$ & $67.5 \%$ & $2.9 \%$ \\
\hline 2b & NT & $21.8 \pm 6.1$ & $28.5 \pm 10.2$ & $13.2 \%$ & $4.4 \%$ \\
\hline $2 c$ & NT & $26.4 \pm 0.2$ & $22.0 \pm 6.1$ & $13.6 \%$ & $4.9 \%$ \\
\hline $3 a$ & NT & $33.0 \pm 13.0$ & $8.0 \pm 1.2$ & $9.4 \%$ & $8.8 \%$ \\
\hline 3b & $7.2 \pm 6.4$ & $26 \pm 0.1$ & NT & $2.4 \%$ & $8.1 \%$ \\
\hline $3 c$ & NT & NT & $5.8 \pm 1.2$ & $14.6 \%$ & $16.1 \%$ \\
\hline 3d & NT & NT & $2.5 \pm 0.3$ & $35.7 \%$ & $4.9 \%$ \\
\hline $4 a$ & $23.4 \pm 8.3$ & $33.3 \pm 6.5$ & $24.9 \pm 3.2$ & $20.7 \%$ & $1.9 \%$ \\
\hline $4 b$ & $32.7 \pm 2.0$ & $33.7 \pm 0.4$ & $27.3 \pm 7.5$ & NT & $9.1 \%$ \\
\hline $4 c$ & $56.2 \pm 0.1$ & $50.2 \pm 13.1$ & $34.4 \pm 2.3$ & $24.9 \%$ & $3.3 \%$ \\
\hline 4d & $46.6 \pm 9.5$ & $47.5 \pm 0.3$ & $45.9 \pm 14.0$ & $16.7 \%$ & $10.2 \%$ \\
\hline $4 e$ & $16.7 \pm 0.3$ & $42.7 \pm 2.0$ & $11.2 \pm 4.0$ & $50.2 \%$ & $42.3 \%$ \\
\hline $4 f$ & $23.7 \pm 9.5$ & $42.2 \pm 15.1$ & $93.5 \pm 1.0$ & $32.1 \%$ & $4.0 \%$ \\
\hline $6 \mathbf{a}$ & $67.1 \pm 5.1$ & $65.3 \pm 2.7$ & $30.2 \pm 3.3$ & $5.0 \%$ & $12.4 \%$ \\
\hline $6 \mathbf{b}$ & $87.0 \pm 11.1$ & $97.1 \pm 3.2$ & $100.0 \pm 1.1$ & $1.4 \%$ & $6.0 \%$ \\
\hline $6 c$ & $32.1 \pm 0.6$ & $41.0 \pm 0.1$ & $50.7 \pm 0.8$ & $0.8 \%$ & $2.6 \%$ \\
\hline 6d & $58.9 \pm 2.3$ & $56.5 \pm 5.5$ & $55.1 \pm 5.7$ & NT & $11.4 \%$ \\
\hline $6 e$ & $62.5 \pm 6.1$ & $62.8 \pm 7.9$ & $60.4 \pm 6.3$ & $19.2 \%$ & $10.7 \%$ \\
\hline $6 \mathbf{f}$ & $96.8 \pm 0.3$ & $91.3 \pm 4.4$ & $82.1 \pm 8$ & $35.6 \%$ & $23.8 \%$ \\
\hline $7 a$ & NT & $25.3 \pm 9.8$ & $35.5 \pm 7.8$ & $13.9 \%$ & $3.4 \%$ \\
\hline $7 \mathbf{b}$ & $64.8 \pm 1.0$ & $45.8 \pm 7.8$ & $28.4 \pm 3.0$ & $59.9 \%$ & $7.8 \%$ \\
\hline 7c & NT & NT & $24.8 \pm 3.3$ & $14.6 \%$ & $14.2 \%$ \\
\hline 7d & $38.5 \pm 1.2$ & $52.3 \pm 1.5$ & $22.8 \pm 1.9$ & $4.0 \%$ & $1.7 \%$ \\
\hline $7 e$ & $7.5 \pm 0.9$ & $9.3 \pm 3.7$ & $16.3 \pm 13.5$ & $1.7 \%$ & $4.4 \%$ \\
\hline $7 f$ & NT & NT & NT & $7.9 \%$ & $2.8 \%$ \\
\hline $7 g$ & $58.7 \pm 3.5$ & $72.5 \pm 3.9$ & $58.5 \pm 1.8$ & $9.8 \%$ & $11.4 \%$ \\
\hline $7 h$ & $11.1 \pm 4.0$ & $24.1 \pm 1.1$ & NT & $17.0 \%$ & $23.2 \%$ \\
\hline Dox & $100.00 \pm 0.7$ & $83.62 \pm 2.9$ & $96.7 \pm 4.5$ & $67.5 \%$ & $2.9 \%$ \\
\hline Thl & $10.4 \pm 4.7$ & $35.7 \pm 3.2$ & $40.5 \pm 7.9$ & $13.2 \%$ & $4.4 \%$ \\
\hline
\end{tabular}

Data are presented as inhibition perceptual of the antiproliferative rate obtained from at least three independent experiments for human tumor lines (SF-295, nervous system; HCT-8, colon; MDA/MB-435, melanoma) and normal human lymphocytes (LYMP). Doxorubicin was used as positive control (Dox); Thalidomide as drug of reference (Thl). NT: non toxic. as positive control, was active against all lines. On the other hand Thalidomide, the phthalimide of reference, was weakly cytotoxic on tumour cells.

Likewise, the $\mathrm{IC}_{50}$ values for compounds $(\mathbf{6 b})$ and $(\mathbf{6 f})$ on human lymphocytes were 9.4 and $7.7 \mu \mathrm{g} / \mathrm{mL}$, respectively. As mentioned before, the selectivity between normal and malignant cells is one of the critical issues for the research and development of chemotherapeutic reagents.

In light of these findings, it is reasonable to draw some comments about the dual behaviour of compounds $(\mathbf{6 b})$ and $(\mathbf{6 f})$. These compounds showed immunosuppressive activity toward TNF $\alpha$ at $10 \mu \mathrm{g} / \mathrm{mL}$ and also showed anticancer properties against three tumour cell lines.

With regard to the structural features of the compounds and the immunological profiles of all series of the tested compounds (Fig. 8), the immunosuppressive and antiproliferative profile of the $(6 a-f)$ series of phthalimide derivatives were the most effective. The main structural difference between the $(\mathbf{6} \mathbf{a}-\mathbf{f})$ and $(\mathbf{4 a}-\mathbf{f})$ series concerns the insertion of a flexible group $\left(-\mathrm{CH}_{2}-\mathrm{CH}=\mathrm{N}-\right.$ ) between the phthalyl and thiazolidinone rings (in the $\mathbf{4 a}-\mathbf{f}$ series). Another remark is the fact that series ( $7 \mathbf{a}-\mathbf{h})$ possesses a 4-phenylthiazole nucleus instead of a thiazolidin-4-one nucleus such as that present in the $(\mathbf{4 a}-\mathbf{f})$ and $(\mathbf{6} \mathbf{a}-\mathbf{f})$ series.

It is worth mentioning that our previous results showed that phthalimide derivatives were inactive $\left(\mathrm{IC}_{50}>300 \mu \mathrm{M}\right)$ in in vitro tests against four tumour cells lines: MDA/MB-435 (breast), HCT-8 (colon), SF-295 (glioblastoma) and HL-60 (leukaemia). Likewise, in general, these derivatives did not show immunosuppressive properties, which is a characteristic that is highly desirable in new immunomodulatory drug candidates [32].

\subsection{Docking studies}

$N F-\kappa B$ is a significant transcription factor that regulates the expression of various pro-survival genes. The multi-subunit protein kinase, IKK, regulates NF- $\kappa \mathrm{B}$ activation in response to specific external mediators, including tumour necrosis factor- $\alpha$ (TNF $\alpha)$ and interleukin-1 (IL-1) [52]. In the nucleus, NF- $\kappa B$ binds to its cognate DNA site and enhances the expression of a number of genes related to the immune response, cell proliferation and survival [53].

Thus, the inhibition of IKK $\beta$ on the NF- $\kappa B$ pathway could be involved the anti-inflammatory and anti-cancer mechanism of the molecules reported in this work.

To understand a possible correlation between cell proliferation inhibition and IKK $\beta$, we investigated the interaction of compounds reported in this work with IKK $\beta$ (PDB ID: 4KIK) by conducting docking studies. The binding mode for these ligands was 

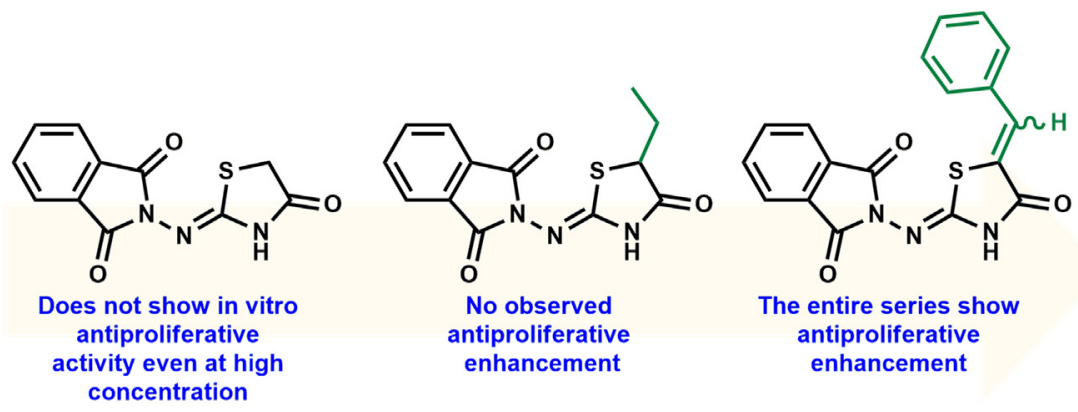

Fig. 8. Effect of substitutions in the thiazole ring on antiproliferative activity.

determined by the highest (most positive) score among the possible solutions for each ligand. These calculations were generated according to the ChemPLP Fitness Score [54].

Fig. 9 shows the trend observed between the in silico docking scores and the cytotoxic activity on tumour cells evaluated by MTT assay. The assay indicates that the compounds with higher cytotoxic action on tumour cells are usually those with the higher docking scores, i.e., the molecules with high cytotoxic action also have a high affinity for the IKK $\beta$ target, as revealed by the docking score values. It is important to highlight the large variation of docking scores (range: from 61.22 to 81.04), and the percentage of inhibition (range: from zero to $100.0 \%$ ), which contributes to the reliability of this in silico-in vitro trend.

To identify the molecular reasons for the two extremes of cell proliferation inhibition (highest and lowest percentage inhibition for (6b) and (3d), respectively), we performed a detailed analysis of the intermolecular interactions between the target (IKK $\beta$ ) and the docked molecules. The superimposition of molecules $(\mathbf{6 b}),(\mathbf{3 d})$ and co-crystallized ligand (named "K252A") can be seen in Fig. 10.

The difference between the binding modes of the (6b) and (3d) molecules is shown in Fig. 11 and Table 3. The residues of the IKK $\beta$ target that participate in hydrophobic interactions, hydrogen bonds and $\pi-\pi$ interactions are highlighted in Fig. 11. It seems that the additional hydrophobicity of the Cl-phenyl group in molecule (6b) provides a greater contact surface for interactions with hydrophobic residues of the target in comparison with molecule (3d), which ensures more stability in the complex formed with IKK $\beta$.

This stability difference is also revealed when we analyse the docking score values for the $(\mathbf{6 b})$ and (3d) molecules, which are 78.07 and 62.15 , respectively. Due to the trend observed between the in silico docking scores (ChemPLP scores) and the in vitro cytotoxic activity on tumour cells, the molecules with high affinity (in silico) for the IKK $\beta$ target seem to prevent more cell proliferation (in vitro), at least for the three tumour lines tested in this work (SF295, HCT-8 and MDA/MB-435).

\section{Conclusions}

The current investigation has described the facile synthesis of anti-cancer compounds, which showed significant cytotoxic activity toward three human cancer cell lines and immunosuppressive activity over cytokines TNF $\alpha$, IFN $\gamma$, IL-2 and IL-6. In silico docking studies have shown that the molecules with more stable or positive docking scores (i.e., greater in silico affinity for the IKK $\beta$ target) are also the most cytotoxic in human cancer cell lines. In summary, compounds (6b) and (6f) hold potential as immunosuppressive agents with anticancer properties. The described findings may open up new possibilities for developing a new class of drugs with immunosuppressive and cytotoxic activity.

\section{Experimental methods}

\subsection{General}

Melting points were measured with a Fisatom (Mod. 430D, $60 \mathrm{~Hz}$ ) melting point apparatus and are uncorrected. ${ }^{1} \mathrm{H}$ NMR

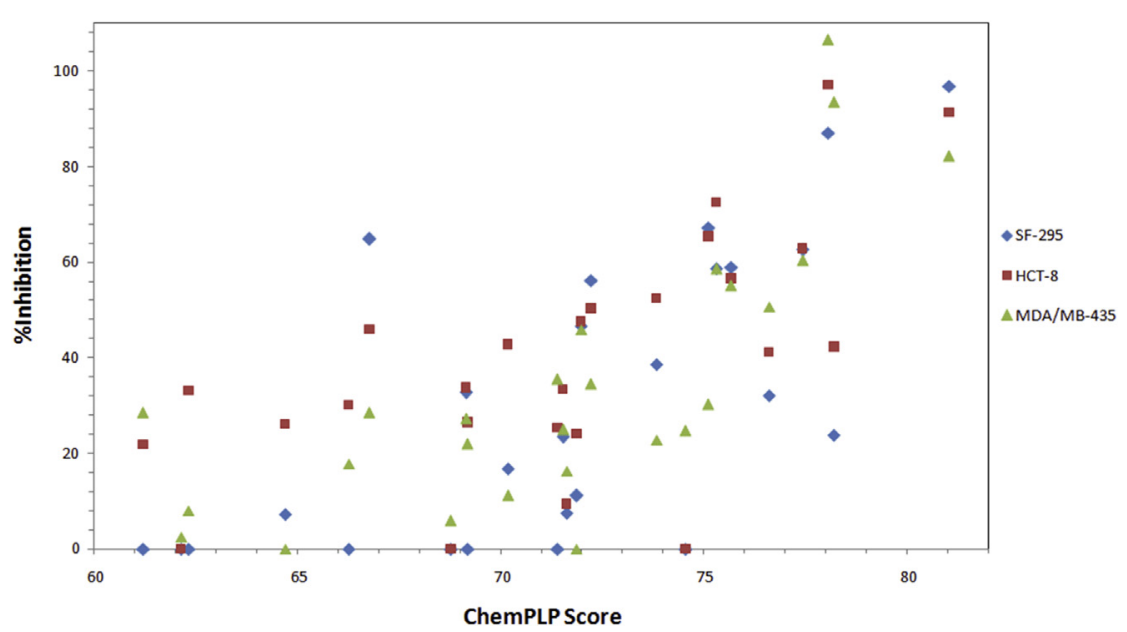

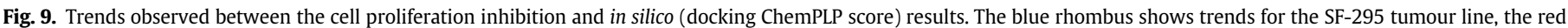

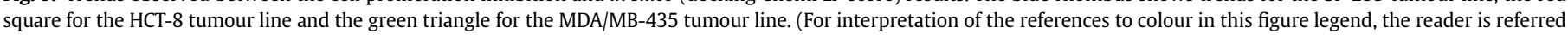
to the web version of this article.) 


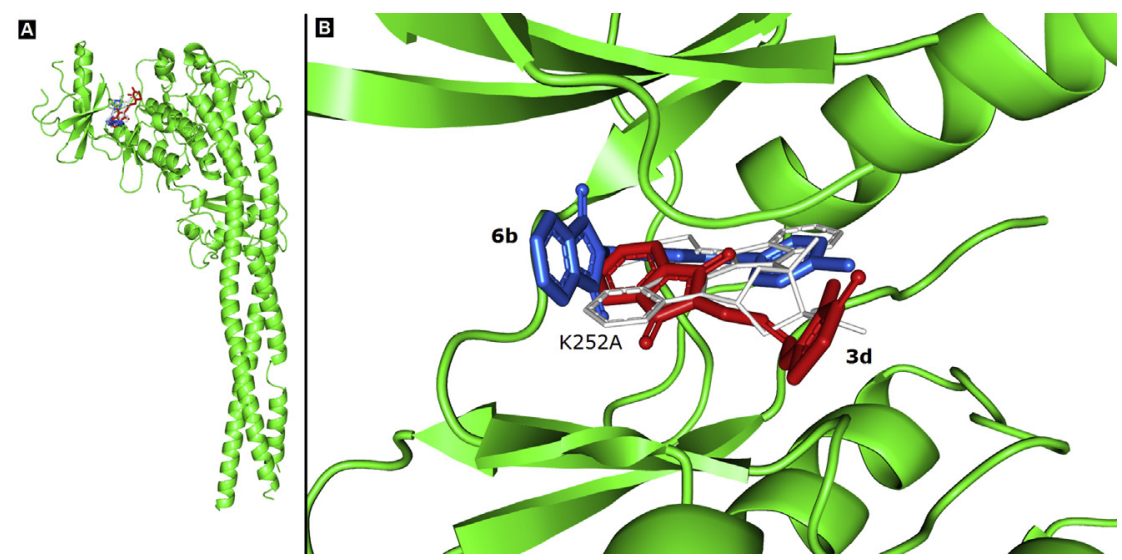

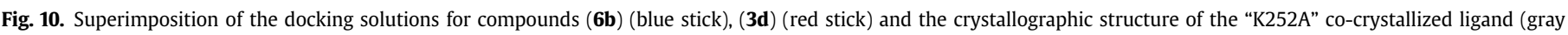
line). (A) Full view and (B) active site view. (For interpretation of the references to colour in this figure legend, the reader is referred to the web version of this article.)
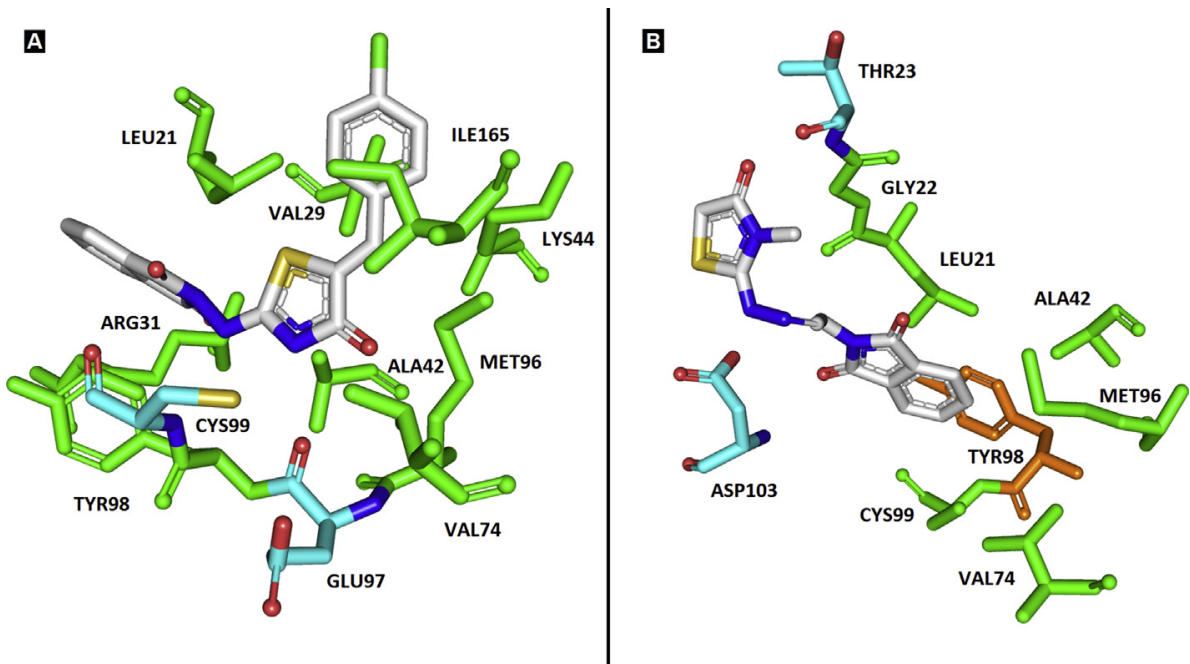

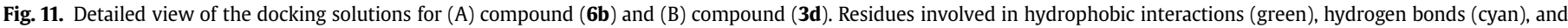

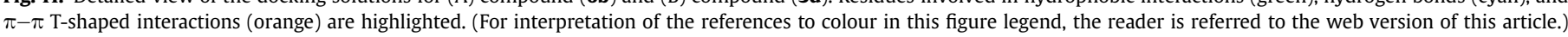

Table 3

Molecular interaction of IKK $\beta$ with molecules (6b) and (3d).

\begin{tabular}{lll}
\hline Residues & Molecules & \\
\cline { 2 - 3 } & $6 \mathrm{~b}$ & $3 \mathrm{~d}$ \\
\hline LEU21 & $\mathrm{HC}$ & $\mathrm{HC}$ \\
GLY22 & - & $\mathrm{HC}$ \\
THR23 & - & 3.0 \\
VAL29 & $\mathrm{HC}$ & - \\
ARG31 & $\mathrm{HC}$ & - \\
ALA42 & $\mathrm{HC}$ & $\mathrm{HC}$ \\
LYS44 & $\mathrm{HC}$ & - \\
VAL74 & $\mathrm{HC}$ & $\mathrm{HC}$ \\
MET96 & $\mathrm{HC}$ & $\mathrm{HC}$ \\
GLU97 & 2.9 & - \\
TYR98 & $\mathrm{HC}$ & $\mathrm{PI}$ \\
CYS99 & 3.3 & $\mathrm{HC}$ \\
ASP103 & - & 3.3 \\
ILE165 & $\mathrm{HC}$ & - \\
\hline Docking score & 78.07 & 62.15 \\
\hline
\end{tabular}

HC means hydrophobic contacts, PI means $\pi-\pi$ interaction, and the numbers are the hydrogen bond distances between donor and acceptor, in Ångstroms. (See Fig. 11). spectra were recorded on a $300 \mathrm{MHz}$ spectrometer in appropriate solvents using TMS as an internal standard or the solvent signals as secondary standards. The chemical shifts are shown in $\delta(\mathrm{ppm})$ scale. Multiplicities of NMR signals are designated as s (singlet), $\mathrm{d}$ (doublet), br (broad) and $\mathrm{m}$ (multiplet, for unresolved lines). ${ }^{13} \mathrm{C}$ NMR spectra were recorded on a $75.5 \mathrm{MHz}$ spectrometer. All the experiments were monitored by analytical thin layer chromatography (TLC) performed on silica gel GF254 pre-coated plates. After elution, plates were visualized under UV illumination at $254 \mathrm{~nm}$ for UV active materials.

\subsection{General procedure for the synthesis of thiazolidinones (3a-d). Example for compound (3a)}

Thiosemicarbazone (2a) ( $0.4 \mathrm{~g}, 1.52 \mathrm{mmol})$, anhydrous sodium acetate $(0.5 \mathrm{~g}, 6.08 \mathrm{mmol})$, and $50 \mathrm{~mL}$ ethanol were added to a $100 \mathrm{~mL}$ round bottom flask under magnetic stirring and slightly warmed for $10-15 \mathrm{~min}$. Then, ethyl 2-bromoacetate $(0.26 \mathrm{~g}$, $1.52 \mathrm{mmol}$ ) was added, and the colourless reaction was kept under reflux heating for $18 \mathrm{~h}$. After cooling the solution back to room temperature (r.t.), the precipitate was filtered off and the solvent was evaporated for half of its volume and then cooled to $0{ }^{\circ} \mathrm{C}$. A white solid was obtained, filtered in a Büchner funnel with a 
sintered disc filter, washed with cold water and then dried in $\mathrm{SiO}_{2}$. Products were purified by recrystallization using the solvent system detailed below for each compound.

\subsubsection{2-(4-Oxothiazolidin-2-ylidene)hydrazono)ethyl)isoindoline- 1,3-dione (3a)}

After crystallization with toluene, colourless crystals were obtained; yield $=74 \%$; M.p. $\left({ }^{\circ} \mathrm{C}\right)$ : 262-263; $\mathrm{IR}(\mathrm{KBr}) 3075(\mathrm{~N}-\mathrm{H}), 2968$ $(\mathrm{C}-\mathrm{H}), 1771$ and $1714(\mathrm{C}=\mathrm{O}), 1641(\mathrm{C}=\mathrm{N}) \mathrm{cm}^{-1}$. ${ }^{1} \mathrm{H} \mathrm{NMR}(300 \mathrm{MHz}$, DMSO- $\left.d_{6}\right): \delta 3.68\left(\mathrm{~s}, 2 \mathrm{H}, \mathrm{CH}_{2}\right.$ heterocycle); $4.47\left(\mathrm{~d}, 2 \mathrm{H}, \mathrm{CH}_{2}\right) ; 7.71(\mathrm{t}$, $1 \mathrm{H}, \mathrm{CH}) ; 7.82-7.92(\mathrm{~m}, 4 \mathrm{H}, \mathrm{Ar}) ; 11.84(\mathrm{~s}, 1 \mathrm{H}, \mathrm{NH}) .{ }^{13} \mathrm{C} \mathrm{NMR}$ (75.5 MHz, DMSO- $\left.d_{6}\right): \delta 32.8\left(\mathrm{CH}_{2}\right.$ heterocycle); $37.6\left(\mathrm{CH}_{2}\right) ; 123.1$ $(\mathrm{CH} \mathrm{Ar}) ; 131.73(\mathrm{CH} \mathrm{Ar}) ; 134.5(\mathrm{Ar}) ; 153.5(\mathrm{HC}=\mathrm{N}) ; 165.7(\mathrm{~S}-\mathrm{C}=\mathrm{N})$; $167.5(\mathrm{C}=0) ; 167.6(\mathrm{C}=0) ; 174.4(\mathrm{C}=\mathrm{O}$ heterocycle). Anal. Calcd. For (3a): C, 51.65; H, 3.33; N, 18.53; S, 10.61; Found: C, 51.42; H, 3.40; N, 18.13; S, 10.36. Rf: 0.35 .

\subsubsection{2-(5-Methyl-4-oxothiazolidin-2-ylidene)hydrazono)ethyl) isoindoline-1,3-dione (3b)}

After crystallization with toluene, colourless crystals were obtained; yield = 70\%; M.p. $\left({ }^{\circ} \mathrm{C}\right): 227$; IR $(\mathrm{KBr}) 3461(\mathrm{~N}-\mathrm{H}), 3034$ $(\mathrm{C}-\mathrm{H}), 1772$ and $1718(\mathrm{C}=\mathrm{O}), 1648(\mathrm{C}=\mathrm{N}) \mathrm{cm}^{-1}$. ${ }^{1} \mathrm{H}$ NMR $(300 \mathrm{MHz}$. DMSO-d $\left.)_{6}\right): \delta 1.35$ (d, 3H, CH $) ; 4.00(\mathrm{q}, 1 \mathrm{H}, \mathrm{CH}) ; 4.47\left(\mathrm{~d}, 2 \mathrm{H}, \mathrm{CH}_{2}\right)$; $7.71(\mathrm{t}, 1 \mathrm{H}, \mathrm{CH}) ; 7.84-7.93(\mathrm{~m}, 4 \mathrm{H}, \mathrm{Ar}) ; 11.82(\mathrm{~s}, 1 \mathrm{H}, \mathrm{NH}) .{ }^{13} \mathrm{C}$ NMR (75.5 MHz, DMSO- $\left.d_{6}\right): \delta 18.7\left(\mathrm{CH}_{3}\right) ; 37.4\left(\mathrm{CH}_{2}\right) ; 42.1(\mathrm{CH}$ heterocycle); 123.2 ( $\mathrm{CH} \mathrm{Ar}) ; 131.7(\mathrm{CH} \mathrm{Ar}) ; 134.6(\mathrm{Ar}) ; 153.8(\mathrm{HC}=\mathrm{N})$; $163.9(\mathrm{~S}-\mathrm{C}=\mathrm{N}) ; 167.5(\mathrm{C}=\mathrm{O}) ; 177.4(\mathrm{C}=\mathrm{O}$ heterocycle $)$. Anal. Calcd. For (3b): C, 53.16; H, 3.82; N, 17.71; S, 10.14; Found: C, 53.55; H, 3.90; N, 17.43; S, 10.08. Rf: 0.526 .

\subsubsection{2-(5-Ethyl-4-oxothiazolidin-2-ylidene)hydrazono)ethyl) isoindoline-1,3-dione (3c)}

After crystallization with toluene, colourless crystals were obtained; yield = 79\%; M.p. $\left({ }^{\circ} \mathrm{C}\right)$ : 191-192; IR $(\mathrm{KBr}) 3397(\mathrm{~N}-\mathrm{H}), 2963$ $(\mathrm{C}-\mathrm{H}), 1770$ and $1714(\mathrm{C}=\mathrm{O}), 1651(\mathrm{C}=\mathrm{N}) \mathrm{cm}^{-1}$. ${ }^{1} \mathrm{H}$ NMR $(300 \mathrm{MHz}$, DMSO-d $\left.)_{6}\right): \delta 0.80\left(\mathrm{t}, 3 \mathrm{H}, \mathrm{CH}_{3}\right) ; 1.59-1.98\left(\mathrm{~m}, 2 \mathrm{H}, \mathrm{CH}_{2}\right) ; 4.36(\mathrm{~d}, 2 \mathrm{H}$, $\left.\mathrm{CH}_{2}\right) ; 7.43(\mathrm{t}, 1 \mathrm{H}, \mathrm{CH}$ heterocycle $) ; 7.68(\mathrm{t}, 1 \mathrm{H}, \mathrm{CH}) ; 7.83-7.91(\mathrm{~m}, 4 \mathrm{H}$, Ar); 11.23 (s, $1 \mathrm{H}, \mathrm{NH}) .{ }^{13} \mathrm{C}$ NMR (75.5 MHz, DMSO-d $): \delta 10.3\left(\mathrm{CH}_{3}\right)$; $25.4\left(\mathrm{CH}_{2}\right) ; 37.6\left(\mathrm{CH}_{2}\right) ; 49.3(\mathrm{CH}$ heterocycle); $123.0(\mathrm{Ar}) ; 131.5(\mathrm{Ar})$; 134.2 $(\mathrm{Ar}) ; 140.3(\mathrm{HC}=\mathrm{N}) ; 152.6(\mathrm{C}=\mathrm{N}) ; 167.3(\mathrm{C}=\mathrm{O}) ; 177.2(\mathrm{C}=\mathrm{O})$; 178.0 ( $\mathrm{C}=\mathrm{O})$. Anal. Calcd. For (3c): C, 54.53; H, 4.27; N, 16.96; S, 9.71; Found: C, 54.37; H, 4.42; N, 17.16; S, 10.05. Rf: 0.5.

\subsubsection{2-(3-Methyl-4-oxothiazolidin-2-ylidene)hydrazono)ethyl) isoindoline-1,3-dione (3d)}

After crystallization with toluene, colourless crystals were obtained; yield =65\%; M.p. $\left({ }^{\circ} \mathrm{C}\right): 180-181$; IR $(\mathrm{KBr}) 2979(\mathrm{C}-\mathrm{H}), 1770$ and $1718(\mathrm{C}=\mathrm{O}), 1637(\mathrm{C}=\mathrm{N}) \mathrm{cm}^{-1}$. ${ }^{1} \mathrm{H}$ NMR (300 MHz. DMSO- $\left.d_{6}\right)$ : $\delta 3.04\left(\mathrm{~s}, 3 \mathrm{H}, \mathrm{CH}_{3}\right) ; 3.74\left(\mathrm{~s}, 2 \mathrm{H}, \mathrm{CH}_{2}\right.$ heterocycle); $4.49\left(\mathrm{~d}, 2 \mathrm{H}, \mathrm{CH}_{2}\right)$; 7.40 (t, $1 \mathrm{H}, \mathrm{CH}) ; 7.83-7.90$ (m, 4H, Ar). ${ }^{13} \mathrm{C}$ NMR (75.5 MHz. DMSO$\left.d_{6}\right): \delta 29.1\left(\mathrm{CH}_{2}\right.$ heterocycle); $30.6\left(\mathrm{CH}_{2}\right) ; 31.81\left(\mathrm{CH}_{3}\right) ; 123.0(\mathrm{CH} \mathrm{Ar})$; $131.6(\mathrm{CH} \mathrm{Ar}) ; 134.4(\mathrm{Ar}) ; 154.8(\mathrm{HC}=\mathrm{N}) ; 164.8(\mathrm{~S}-\mathrm{C}=\mathrm{N}) ; 167.4$ $(\mathrm{C}=\mathrm{O}) ; 172.1(\mathrm{C}=\mathrm{O}) ; 178.0(\mathrm{C}=\mathrm{O}$ heterocycle). Anal. Calcd. For (3d): C, 51.16; H, 3.82; N, 17.71; S, 10.14; Found: C, 51.40; H, 4.02; N, 17.42; S, 9.89. Rf: 0.562 .

\subsection{General procedure for the synthesis of benzylidenes $(\mathbf{4 a}-\boldsymbol{f})$. Example for benzylidene (4a)}

Thiazolidinone (3a) (0.4 g, $1.32 \mathrm{mmol})$, anhydrous potassium acetate $(0.39 \mathrm{~g}, 3.96 \mathrm{mmol})$, and $5 \mathrm{~mL}$ dimethylformamide were added to a $100 \mathrm{~mL}$ round bottom flask under magnetic stirring and slightly warmed for $10-15 \mathrm{~min}$. Then 4 -fluorobenzaldehyde $(0.16 \mathrm{~g}$, $1.32 \mathrm{mmol}$ ) was added and the reaction acquired yellow colour was kept under heating under reflux for $24 \mathrm{~h}$. After cooling back to r.t., water was added to the flask and a yellow precipitate was formed. The precipitate was filtered off and the solvent was discarded. A yellow solid is obtained, filtered in Büchner funnel with sintered disc filter, washed with cold water, and then dried in $\mathrm{SiO}_{2}$. Products are purified by column chromatography using the solvent system detailed below for each compound.

\subsubsection{2-(2-((-5-(4-Fluorobenzylidene)-4-oxothiazolidin-2-ylidene)} hydrazono)ethyl)isoindoline-1,3-dione (4a)

After elution with hexane/acetate (8:2), yellow crystals were obtained; yield $=38 \%$; M.p. $\left({ }^{\circ} \mathrm{C}\right)$ : unidentified to $300{ }^{\circ} \mathrm{C}$; IR $(\mathrm{KBr})$ $3471(\mathrm{~N}-\mathrm{H}), 2935(\mathrm{C}-\mathrm{H}), 1716(\mathrm{C}=\mathrm{O}), 1634$ and $1600(\mathrm{C}=\mathrm{N}), 1233$ $(\mathrm{C}-\mathrm{F}) \mathrm{cm}^{-1}$. ${ }^{1} \mathrm{H}$ NMR $\left(300 \mathrm{MHz}\right.$, DMSO-d $\left.{ }_{6}\right): \delta 4.32\left(\mathrm{~d}, 2 \mathrm{H}, \mathrm{CH}_{2}\right) ; 7.22$ (d, 2H, Ar); $7.48(\mathrm{t}, 1 \mathrm{H}, \mathrm{CH}) ; 7.69(\mathrm{~s}, 1 \mathrm{H}, \mathrm{CH}) ; 7.72(\mathrm{~d}, 2 \mathrm{H}, \mathrm{Ar})$; 7.79-7.96 (m, 4H, Ar); 8.52 (s, $1 \mathrm{H}, \mathrm{NH}) .{ }^{13} \mathrm{C}$ NMR (75.5 MHz, DMSO$\left.d_{6}\right): \delta 37.6\left(\mathrm{CH}_{2}\right) ; 115.1(\mathrm{~S}-\mathrm{C}=\mathrm{C}) ; 120.4(\mathrm{CH} \mathrm{Ar}) ; 130.8(\mathrm{CH} \mathrm{Ar})$; 123.6 ( $\mathrm{CH} \mathrm{Ar}) ; 131.8$ ( $\mathrm{CH} \mathrm{Ar}) ; 132.2(\mathrm{Ar}) ; 132.7(\mathrm{Ar}) ; 142(\mathrm{HC}=\mathrm{C})$; $162.1(\mathrm{C}-\mathrm{F}) ; 163(\mathrm{C}=\mathrm{N}) ; 163.7(\mathrm{HC}=\mathrm{N}) ; 168.2(\mathrm{C}=\mathrm{O}) ; 170.2(\overline{\mathrm{C}}=\mathrm{O})$. Anal. Calcd. For (4a): C, 58.82; H, 3.21; N, 13.72; S, 7.85; Found: C, 58.74; H, 3.48; N, 13.81; S, 8.03. Rf: 0.631.

\subsubsection{2-(2-((-5-(4-Chlorobenzylidene)-4-oxothiazolidin-2-ylidene)} hydrazono)ethyl)isoindoline-1,3-dione (4b)

After elution with hexane/acetate (8:2), yellow crystals were obtained; yield $=46 \%$; M.p. $\left({ }^{\circ} \mathrm{C}\right)$ : unidentified to $300{ }^{\circ} \mathrm{C}$; IR $(\mathrm{KBr})$ $2925(\mathrm{C}-\mathrm{H}), 1724(\mathrm{C}=\mathrm{O}), 1596(\mathrm{C}=\mathrm{N}), 821(\mathrm{C}-\mathrm{Cl}) \mathrm{cm}^{-1} .{ }^{1} \mathrm{H}$ NMR (300 MHz, DMSO- $\left.d_{6}\right): \delta 4.35\left(\mathrm{~d}, 2 \mathrm{H}, \mathrm{CH}_{2}\right) ; 7.55(\mathrm{t}, 1 \mathrm{H}, \mathrm{CH}) ; 7.60(\mathrm{~d}$, 2H, Ar); 7.63 (s, 1H, CH); 7.67 (d, 2H, Ar); 7.82-7.99 (m, 4H, Ar); 8.54 $(\mathrm{s}, 1 \mathrm{H}, \mathrm{NH}) .{ }^{13} \mathrm{C}$ NMR $(75.5 \mathrm{MHz}$, DMSO-d $): \delta 37.6\left(\mathrm{CH}_{2}\right) ; 116.0$ $(\mathrm{S}-\mathrm{C}=\mathrm{C}) ; 123.3$ (CH Ar); $129.5(\mathrm{CH} \mathrm{Ar}) ; 129.7(\mathrm{CH} \mathrm{Ar}) ; 131.9(\mathrm{CH}$ $\mathrm{Ar}) ; 133.3(\mathrm{Ar}) ; 133.5(\mathrm{Ar}) ; 134.7(\mathrm{Ar}) ; 142(\mathrm{HC}=\mathrm{C}) ; 163.7(\mathrm{HC}=\mathrm{N})$; $165.0(\mathrm{C}=\mathrm{N}) ; 168.2(\mathrm{C}=\mathrm{O}) ; 170.0(\mathrm{C}=\mathrm{O}) ; 170.2(\mathrm{C}=\mathrm{O})$. Anal. Calcd. For (4b): C, 56.54; H, 3.08; N, 13.19; S, 7.55; Found: C, 56.37; H, 3.07; N, 13.49; S, 7.77. Rf: 0.635 .

\subsubsection{2-(2-((-5-(4-Bromobenzylidene)-4-oxothiazolidin-2-ylidene) hydrazono)ethyl)isoindoline-1,3-dione (4c)}

After elution with hexane/acetate (8:2), yellow crystals were obtained; yield $=60 \%$; M.p. $\left({ }^{\circ} \mathrm{C}\right)$ : unidentified to $300{ }^{\circ} \mathrm{C}$; $\mathrm{IR}(\mathrm{KBr})$ $2933(\mathrm{C}-\mathrm{H}), 1716(\mathrm{C}=\mathrm{O}), 1607(\mathrm{C}=\mathrm{N}), 558(\mathrm{C}-\mathrm{Br}) \mathrm{cm}^{-1} .{ }^{1} \mathrm{H}$ NMR $\left(300 \mathrm{MHz}, \mathrm{DMSO}-\mathrm{d}_{6}\right): \delta 4.37\left(\mathrm{~d}, 2 \mathrm{H}, \mathrm{CH}_{2}\right) ; 7.50(\mathrm{t}, 1 \mathrm{H}, \mathrm{CH}) ; 7.55(\mathrm{~d}$, $2 \mathrm{H}, \mathrm{Ar}) ; 7.64$ (d, 2H, Ar); 7.72 (s, 1H, CH); 7.80-8.06 (m, 4H, Ar); 8.55 (s, $1 \mathrm{H}, \mathrm{NH}) .{ }^{13} \mathrm{C}$ NMR $\left(75.5 \mathrm{MHz}, \mathrm{DMSO}-\mathrm{d}_{6}\right): \delta 37.6\left(\mathrm{CH}_{2}\right) ; 116.3$ $(\mathrm{S}-\mathrm{C}=\mathrm{C}) ; 122.3$ ( $\mathrm{CH} \mathrm{Ar}) ; 122.9(\mathrm{CH} \mathrm{Ar}) ; 128.6(\mathrm{CH} \mathrm{Ar}) ; 131.5(\mathrm{CH}$ $\mathrm{Ar}) ; 132.3(\mathrm{Ar}) ; 132.7(\mathrm{Ar}) ; 134.2(\mathrm{Ar}) ; 142(\mathrm{HC}=\mathrm{C}) ; 163.7(\mathrm{HC}=\mathrm{N})$; $164(\mathrm{C}=\mathrm{N}) ; 168.4(\mathrm{C}=\mathrm{O}) ; 173.1(\mathrm{C}=\mathrm{O})$. Anal. Calcd. For $(4 \mathrm{c})$ : $\mathrm{C}$, 51.18; H, 2.79; N, 11.94; S, 6.83; Found: C, 50.99; H, 2.76; N, 11.80; S, 7.11. Rf: 0.625 .

\subsubsection{2-(2-((-5-Benzylidene-4-oxothiazolidin-2-ylidene)}

hydrazono)ethyl)isoindoline-1,3-dione (4d)

After elution with hexane/acetate (8:2), yellow crystals were obtained; yield $=56 \%$; M.p. $\left({ }^{\circ} \mathrm{C}\right)$ : unidentified to $300{ }^{\circ} \mathrm{C}$; IR $(\mathrm{KBr})$ $3026(\mathrm{C}-\mathrm{H}), 1715(\mathrm{C}=\mathrm{O}), 1608(\mathrm{C}=\mathrm{N}) \mathrm{cm}^{-1} \cdot{ }^{1} \mathrm{H}$ NMR $(300 \mathrm{MHz}$, DMSO-d $\left.d_{6}\right): \delta 3.95\left(\mathrm{~d}, 2 \mathrm{H}, \mathrm{CH}_{2}\right) ; 7.53(\mathrm{t}, 1 \mathrm{H}, \mathrm{CH}) ; 7.41-7.89(\mathrm{~m}, 10 \mathrm{H}$; $9 \mathrm{H} \mathrm{Ar}$ and $1 \mathrm{H} \mathrm{CH}) ; 8.50(\mathrm{NH}) .{ }^{13} \mathrm{C} \mathrm{NMR}\left(75.5 \mathrm{MHz}\right.$, DMSO- $\left.d_{6}\right): \delta 40.3$ $\left(\mathrm{CH}_{2}\right) ; 116.0(\mathrm{~S}-\mathrm{C}=\mathrm{C}) ; 122.9$ ( $\left.\mathrm{CH} \mathrm{Ar}\right) ; 127.3(\mathrm{CH} \mathrm{Ar}) ; 127.9$ (CH Ar); 128.8 ( $\mathrm{CH} \mathrm{Ar}) ; 132.3$ (CH Ar); 133.7 ( $\mathrm{Ar}) ; 135.2(\mathrm{Ar}) ; 142.5(\mathrm{HC}=\mathrm{C})$; 158.4 $(\mathrm{HC}=\mathrm{N}) ; 159.9(\mathrm{C}=\mathrm{N}) ; 164.6(\mathrm{C}=\mathrm{O}) ; 168(\mathrm{C}=\mathrm{O})$. Anal. Calcd. For (4d): C, 61.53; H, 3.61; N, 14.35; S, 8.21; Found: C, 61.47; H, 3.77; N, 14.77; S, 8.49. Rf: 0.66 .

\subsubsection{2-(2-((-5-(3-Methoxybenzylidene)-4-oxothiazolidin-2-} ylidene)hydrazono)ethyl)isoindoline-1,3-dione (4e)

After elution with hexane/acetate (8:2), yellow crystals were 
obtained; yield $=57 \%$; M.p. $\left({ }^{\circ} \mathrm{C}\right)$ : unidentified to $300{ }^{\circ} \mathrm{C}$; IR $(\mathrm{KBr})$ $3402(\mathrm{~N}-\mathrm{H}), 2952(\mathrm{C}-\mathrm{H}), 1718(\mathrm{C}=\mathrm{O}), 1642$ and $1594(\mathrm{C}=\mathrm{N}), 1265$ $(\mathrm{C}-\mathrm{O}) \mathrm{cm}^{-1} .{ }^{1} \mathrm{H}$ NMR $\left(300 \mathrm{MHz}, \mathrm{DMSO}-d_{6}\right): \delta 3.80\left(\mathrm{~s}, 1 \mathrm{H}, \mathrm{CH}_{3}\right) ; 4.53$ $\left(\mathrm{d}, 2 \mathrm{H}, \mathrm{CH}_{2}\right) ; 6.89-7.85(\mathrm{~m}, 10 \mathrm{H} ; 8 \mathrm{H} \mathrm{Ar}$ and $2 \mathrm{H} \mathrm{CH}) ; 8.55(\mathrm{NH}) .{ }^{13} \mathrm{C}$ NMR (75.5 MHz, DMSO- $\left.d_{6}\right): \delta 43.1\left(\mathrm{CH}_{2}\right) ; 56.8\left(\mathrm{CH}_{3}\right) ; 113.5(\mathrm{CH} \mathrm{Ar})$; 116.0 (S- $-\mathrm{C}=\mathrm{C}) ; 120.9$ (CH Ar); 124.2 ( $\mathrm{CH} \mathrm{Ar}) ; 127.9$ (CH Ar); 130.8 $(\mathrm{Ar}) ; 134.0(\mathrm{Ar}) ; 136.2(\mathrm{HC}=\mathrm{C}) ; 158.3(\mathrm{HC}=\mathrm{N}) ; 159.9(\mathrm{C}-\mathrm{O} \mathrm{Ar})$; $168.0(\mathrm{C}=\mathrm{O})$; $168.2(\mathrm{C}=\mathrm{O})$. Anal. Calcd. For (4e): C, 59.99; H, 3.84; N, 13.33; S, 7.63; Found: C, 59.56; H, 3.78; N, 12.94; S, 7.28. Rf: 0.58 .

\subsubsection{2-(2-((-5-(4-Methoxybenzylidene)-4-oxothiazolidin-2-}

ylidene)hydrazono)ethyl)isoindoline-1,3-dione (4f)

After elution with hexane/acetate (8:2), yellow crystals were obtained; yield $=35 \%$; M.p. $\left({ }^{\circ} \mathrm{C}\right)$ : unidentified to $300{ }^{\circ} \mathrm{C}$; IR $(\mathrm{KBr})$ $2932(\mathrm{C}-\mathrm{H}), 1717(\mathrm{C}=\mathrm{O}), 1597(\mathrm{C}=\mathrm{N}), 1256(\mathrm{C}-\mathrm{O}) \mathrm{cm}^{-1} .{ }^{1} \mathrm{H}$ NMR (300 MHz, DMSO-d $\left.d_{6}\right): \delta 3.85\left(\mathrm{~s}, 1 \mathrm{H}, \mathrm{CH}_{3}\right) ; 4.56\left(\mathrm{~d}, 2 \mathrm{H}, \mathrm{CH}_{2}\right) ; 6.99(\mathrm{~d}$, $2 \mathrm{H}, \mathrm{Ar}) ; 7.51(\mathrm{t}, 1 \mathrm{H}, \mathrm{CH}) ; 7.63(\mathrm{~d}, 2 \mathrm{H}, \mathrm{Ar}) ; 7.73(\mathrm{~s}, 1 \mathrm{H}, \mathrm{CH}) ; 7.83-7.88$ $(\mathrm{m}, 4 \mathrm{H}, \mathrm{Ar}) ; 8.55(\mathrm{NH}) .{ }^{13} \mathrm{C} \mathrm{NMR}\left(75.5 \mathrm{MHz}, \mathrm{DMSO}-d_{6}\right): \delta 40.1\left(\mathrm{CH}_{2}\right)$; $57.1\left(\mathrm{CH}_{3}\right) ; 114.6(\mathrm{CH} \mathrm{Ar}) ; 116.0(\mathrm{~S}-\mathrm{C}=\mathrm{C}) ; 123.3(\mathrm{CH} \mathrm{Ar}) ; 128.4(\mathrm{CH}$ $\mathrm{Ar}) ; 130.7(\mathrm{CH} \mathrm{Ar}) ; 132.0(\mathrm{Ar}) ; 142.0(\mathrm{HC}=\mathrm{C}) ; 157.9(\mathrm{C}-\mathrm{O} \mathrm{Ar}) ; 159.7$ $(\mathrm{HC}=\mathrm{N}) ; 160(\mathrm{C}=\mathrm{N}) ; 163.3(\mathrm{C}=\mathrm{O}) ; 168.2(\mathrm{C}=\mathrm{O})$. Anal. Calcd. For (4f): C, 59.99; H, 3.84; N, 13.33; S, 7.63; Found: C, 59.67; H, 3.62; N, 13.47; S, 7.57. Rf: 0.632 .

\subsection{General procedure for the synthesis of benzylidenes $(\boldsymbol{6 a}-\boldsymbol{f})$. Example for benzylidene (6a)}

Thiazolidinone (5) (0.4 g, $1.52 \mathrm{mmol})$, anhydrous potassium acetate $(0.45 \mathrm{~g}, 4.56 \mathrm{mmol})$, and $5 \mathrm{~mL}$ of dimethylformamide were added to a $100 \mathrm{~mL}$ round bottom flask under magnetic stirring and slightly warmed for $10-15 \mathrm{~min}$. Next, 4-fluorobenzaldehyde (0.19 g, $1.52 \mathrm{mmol}$ ) was added, and the reaction acquired a yellow colour and was kept under heating under reflux for $24 \mathrm{~h}$. After cooling back to r.t., water was added to the flask and a yellow precipitate was formed. The precipitate was filtered off and the solvent was discarded. A yellow solid was obtained, filtered in Büchner funnel with a sintered disc filter, washed with cold water, and then dried in $\mathrm{SiO}_{2}$. Products were purified by column chromatography using the solvent system detailed below for each compound.

\subsubsection{2-((-5-(4-Fluorobenzylidene)-4-oxothiazolidin-2-ylidene) amino)isoindoline-1,3-dione (6a)}

After elution with hexane/acetate (6:4), yellow crystals were obtained; yield $=36 \%$; M.p. $\left({ }^{\circ} \mathrm{C}\right)$ : unidentified to $300{ }^{\circ} \mathrm{C}$; IR $(\mathrm{KBr})$ $2950(\mathrm{C}-\mathrm{H}), 1709(\mathrm{C}=\mathrm{O}), 1651$ and $1598(\mathrm{C}=\mathrm{N}), 1231(\mathrm{C}-\mathrm{F}) \mathrm{cm}^{-1}$. ${ }^{1} \mathrm{H}$ NMR (300 MHz, DMSO- $d_{6}$ ): $\delta 7.21$ (d, 2H, Ar); 7.61 (d, 2H, Ar); $7.72(\mathrm{~s}, 1 \mathrm{H}, \mathrm{CH}) ; 7.84-7.88(\mathrm{~m}, 4 \mathrm{H}, \mathrm{Ar}) ; 8.40(\mathrm{~s}, 1 \mathrm{H}, \mathrm{NH}) .{ }^{13} \mathrm{C} \mathrm{NMR}$ (75.5 MHz, DMSO-d $): \delta 115.4(\mathrm{CH} \mathrm{Ar}) ; 116.0(\mathrm{~S}-\mathrm{C}=\mathrm{C}) ; 122.8(\mathrm{CH}$ $\mathrm{Ar}) ; 124.9(\mathrm{CH} \mathrm{Ar}) ; 127.4(\mathrm{CH} \mathrm{Ar}) ; 131.6(\mathrm{Ar}) ; 132.2(\mathrm{Ar}) ; 133.0(\mathrm{HC}=$ C); $141.6(\mathrm{C}=\mathrm{N}) ; 144.7(\mathrm{C}-\mathrm{F} \mathrm{Ar}) ; 167.7(\mathrm{C}=\mathrm{O}) ; 169.8(\mathrm{C}=\mathrm{O}) ; 1 \overline{75.1}$ $(\mathrm{C}=0)$. Anal. Calcd. For (6a): C, 58.85; H, 2.74; N, 11.44; S, 8.73; Found: C, 58.83; H, 2.58; N, 11.51; S, 8.56. Rf: 0.697.

\subsubsection{2-((-5-(4-Chlorobenzylidene)-4-oxothiazolidin-2-ylidene) amino)isoindoline-1,3-dione (6b)}

After elution with hexane/acetate (6:4), yellow crystals were obtained; yield $=51 \%$; M.p. $\left({ }^{\circ} \mathrm{C}\right)$ : unidentified to $300{ }^{\circ} \mathrm{C}$; IR $(\mathrm{KBr})$ $2938(\mathrm{C}-\mathrm{H}), 1708(\mathrm{C}=\mathrm{O}), 1647(\mathrm{C}=\mathrm{N}), 745(\mathrm{C}-\mathrm{Cl}) \mathrm{cm}^{-1} .{ }^{1} \mathrm{H}$ NMR (300 MHz, DMSO- $\left.d_{6}\right): \delta 7.40$ (d, 2H, Ar); $7.62(\mathrm{~d}, 2 \mathrm{H}, \mathrm{Ar}) ; 7.71(\mathrm{~s}, 1 \mathrm{H}$, $\mathrm{CH}) ; 7.85-7.89$ (m, 4H, Ar); 8.57 (s, $1 \mathrm{H}, \mathrm{NH}) .{ }^{13} \mathrm{C}$ NMR $(75.5 \mathrm{MHz}$, DMSO- $\left.d_{6}\right): \delta 115.0(\mathrm{~S}-\mathrm{C}=\mathrm{C}) ; 125.3(\mathrm{CH} \mathrm{Ar}) ; 128.8$ (CH Ar); 129.0 (CH Ar); 131.9 (CH Ar). 132.2 (Ar); 133.5 (Ar); 133.7 (C-Cl Ar); 140.5 $(\mathrm{HC}=\mathrm{C}) ; 144.1(\mathrm{C}=\mathrm{N}) ; 159.8(\mathrm{C}=0) ; 161.3(\mathrm{C}=0)$. Anal. Calcd. For $(\mathbf{6 b})$ : C, 56.33; H, 2.63; N, 10.95; S, 8.35; Found: C, 56.20; H, 2.32; N, 10.96; S, 8.17. Rf: 0.526 .

\subsubsection{2-((-5-(4-Bromobenzylidene)-4-oxothiazolidin-2-ylidene)} amino)isoindoline-1,3-dione (6c)

After elution with hexane/acetate (6:4), yellow crystals were obtained; yield = 33\%; M.p. $\left({ }^{\circ} \mathrm{C}\right)$ : unidentified to $300{ }^{\circ} \mathrm{C}$; $\mathrm{IR}(\mathrm{KBr})$ $3434(\mathrm{NH}), 2937(\mathrm{C}-\mathrm{H}), 1715(\mathrm{C}=\mathrm{O}), 1645$ and $1583(\mathrm{C}=\mathrm{N}), 558$ $(\mathrm{C}-\mathrm{Br}) \mathrm{cm}^{-1} .{ }^{1} \mathrm{H}$ NMR $\left(300 \mathrm{MHz}, \mathrm{DMSO}-d_{6}\right): \delta 7.53(\mathrm{~d}, 2 \mathrm{H}, \mathrm{Ar}) ; 7.61$ (d, 2H, Ar); $7.73(\mathrm{~s}, 1 \mathrm{H}, \mathrm{CH}) ; 7.86-7.90(\mathrm{~m}, 4 \mathrm{H}, \mathrm{Ar}) ; 8.59(\mathrm{~s}, 1 \mathrm{H}, \mathrm{NH})$. ${ }^{13} \mathrm{C}$ NMR (75.5 MHz, DMSO- $\left.d_{6}\right): \delta 116.0(\mathrm{~S}-\mathrm{C}=\mathrm{C}) ; 122.5(\mathrm{CH} \mathrm{Ar}) ;$ 128.7 (CH Ar); 124.0 (CH Ar). 131.3 (CH Ar); $132.0(\mathrm{Ar}) ; 132.3(\mathrm{CH}$ $\mathrm{Ar}) ; 142.0(\mathrm{HC}=\mathrm{C}) ; 144.6(\mathrm{C}=\mathrm{N}) ; 159.9(\mathrm{C}=\mathrm{O}) ; 165.4(\mathrm{C}=\mathrm{O})$. Anal. Calcd. For (6c): C, 50.48; H, 2.35; N, 9.81; S, 7.49; Found: C, 50.22; H, 2.58; N, 9.62; S, 7.20. Rf: 0.552.

\subsubsection{2-((-5-Benzylidene-4-oxothiazolidin-2-ylidene)amino) isoindoline-1,3-dione (6d)}

After elution with hexane/acetate (6:4), yellow crystals were obtained; yield $=40 \%$; M.p. $\left({ }^{\circ} \mathrm{C}\right)$ : unidentified to $300{ }^{\circ} \mathrm{C}$; IR $(\mathrm{KBr})$ 3023 and $2951(\mathrm{C}-\mathrm{H}), 1712(\mathrm{C}=\mathrm{O}), 1646$ and $1593(\mathrm{C}=\mathrm{N}) \mathrm{cm}^{-1} \cdot{ }^{1} \mathrm{H}$ NMR (300 MHz, DMSO- $\left.d_{6}\right): \delta 7.45-7.85(\mathrm{~m}, 9 \mathrm{H}, \mathrm{Ar}) ; 8.40(\mathrm{~s}, 1 \mathrm{H}$, $\mathrm{CH}) ; 8.51(\mathrm{~s}, 1 \mathrm{H}, \mathrm{NH}) .{ }^{13} \mathrm{C} \mathrm{NMR}\left(75.5 \mathrm{MHz}\right.$, DMSO-d $\left.d_{6}\right): \delta 115.6(\mathrm{~S}-\mathrm{C}=$ C); 128.6 ( $\mathrm{CH} \mathrm{Ar}) ; 128.8$ ( $\mathrm{CH} \mathrm{Ar}) ; 129.8$ ( $\mathrm{CH} \mathrm{Ar}) ; 129.9$ ( $\mathrm{CH} \mathrm{Ar}) ; 13 \overline{0} .2$ ( $\mathrm{CH} \mathrm{Ar}) ; 130.6(\mathrm{Ar}) ; 130.8(\mathrm{Ar}) ; 131.8(\mathrm{HC}=\mathrm{C}) ; 134.8(\mathrm{C}=\mathrm{N}) ; 157.2$ $(C=0) ; 158.0(C=0)$. Anal. Calcd. For $(\mathbf{6 d})$ : C, 61.88; H, 3.17; , 12.03; S, 9.18; Found: C, 61.50; H, 3,28; N, 12.39; S, 9.46. Rf: 0.592.

4.4.5. 2-((-5-(3-Methoxybenzylidene)-4-oxothiazolidin-2-ylidene) amino)isoindoline-1,3-dione (6e)

After elution with hexane/acetate (6:4), yellow crystals were obtained; yield $=22 \%$; M.p. $\left({ }^{\circ} \mathrm{C}\right)$ : unidentified to $300{ }^{\circ} \mathrm{C}$; IR $(\mathrm{KBr})$ $3460(\mathrm{~N}-\mathrm{H}), 2936(\mathrm{C}-\mathrm{H}), 1711(\mathrm{C}=\mathrm{O}), 1641$ and $1594(\mathrm{C}=\mathrm{N}), 1266$ (C-O) $\mathrm{cm}^{-1} .{ }^{1} \mathrm{H}$ NMR (300 MHz, DMSO-d $): \delta 3.99\left(\mathrm{~s}, 3 \mathrm{H}, \mathrm{CH}_{3}\right)$; 6.89-7.46 (m, 4H, Ar). 7.72 (s, 1H, CH); 7.85-7.88 (m, 4H, Ar); 8.51 $(\mathrm{NH}) .{ }^{13} \mathrm{C}$ NMR $\left(75.5 \mathrm{MHz}\right.$, DMSO-d $\left.d_{6}\right): \delta 57.2\left(\mathrm{CH}_{3}\right) ; 114.3(\mathrm{CH} \mathrm{Ar})$; $116.0(\mathrm{~S}-\mathrm{C}=\mathrm{C}) ; 120.1(\mathrm{CH} \mathrm{Ar}) ; 122.6(\mathrm{CH} \mathrm{Ar}) ; 128.2(\mathrm{CH} \mathrm{Ar}) ; 132.5$ (CH Ar). $132.8(\mathrm{Ar}) ; 136.8(\mathrm{Ar}) ; 139.1(\mathrm{HC}=\mathrm{C}) ; 142.0(\mathrm{C}=\mathrm{N}) ; 157.4$ $(\mathrm{C}-\mathrm{O} \mathrm{Ar}) ; 159.2(\mathrm{C}=\mathrm{O})$; 163.6 $(\mathrm{C}=\mathrm{O})$. Anal. Calcd. For $(\mathbf{6 e})$ : C, 60.15; H, 3.45; N, 11.08; S, 8.45; Found: C, 60.01; H, 3.25; N, 11.20; S, 8.47. Rf: 0.578 .

\subsubsection{2-((-5-(4-Methoxybenzylidene)-4-oxothiazolidin-2-ylidene)} amino)isoindoline-1,3-dione (6f)

After elution with hexane/acetate (6:4), yellow crystals were obtained; yield $=46 \%$; M.p. $\left({ }^{\circ} \mathrm{C}\right)$ : unidentified to $300{ }^{\circ} \mathrm{C}$; IR $(\mathrm{KBr})$ $2952(\mathrm{C}-\mathrm{H}), 1710(\mathrm{C}=\mathrm{O}), 1651$ and $1598(\mathrm{C}=\mathrm{N}), 1255(\mathrm{C}-\mathrm{O}) \mathrm{cm}^{-1}$. ${ }^{1} \mathrm{H}$ NMR (300 MHz, DMSO- $\left.d_{6}\right): \delta 4.01\left(\mathrm{~s}, 3 \mathrm{H}, \mathrm{CH}_{3}\right) ; 6.69$ (d, $\left.2 \mathrm{H}, \mathrm{Ar}\right)$; 7.65 (d, 2H, Ar); $7.84-7.89$ (m, 4H, Ar); 8.38 (s, 1H, CH); 8.49 (s, 1H, $\mathrm{NH}) .{ }^{13} \mathrm{C}$ NMR $\left(75.5 \mathrm{MHz}, \mathrm{DMSO}-d_{6}\right): \delta 55.9\left(\mathrm{CH}_{3}\right) ; 115.2(\mathrm{CH} \mathrm{Ar})$; $116.0(\mathrm{~S}-\mathrm{C}=\mathrm{C}) ; 124.4$ (CH Ar); 128.3 ( $\mathrm{CH} \mathrm{Ar}) ; 132.1$ (CH Ar); 133.6 $(\mathrm{Ar}) ; 133.9(\mathrm{Ar}) ; 142.8(\mathrm{HC}=\mathrm{C}) ; 144.3(\mathrm{C}=\mathrm{N}) ; 148.3(\mathrm{C}-\mathrm{O} \mathrm{Ar}) ; 160.3$ $(C=0) ; 163.2(C=0)$. Anal. Calcd. For $(\mathbf{6 f})$ : C, 60.15; H, 3.45; N, 11.08; S, 8.45; Found: C, 60.48; H, 3.74; N, 11.05; S, 8.23. Rf: 0.605 .

\subsection{General procedure for the synthesis of 1,3-thiazoles (7a-h).} Example for thiazole (7a)

Thiosemicarbazone (2a) ( $0.15 \mathrm{~g}, 0.57 \mathrm{mmol})$, anhydrous sodium acetate $(0.18 \mathrm{~g}, 2.28 \mathrm{mmol})$, and $50 \mathrm{~mL}$ ethanol were added to a $100 \mathrm{~mL}$ round bottom flask under magnetic stirring and slightly warmed for 10-15 min. Then, 2-bromoacetophenone (0.11 g, $0.57 \mathrm{mmol}$ ) was added, and the reaction acquired purple colour and was kept under heating under reflux for $4 \mathrm{~h}$. After cooling back to r.t., the precipitate was filtered off and the solvent was evaporated for half of its volume and then cooled to $0^{\circ} \mathrm{C}$. A purple solid was obtained, filtered in Büchner funnel with a sintered disc filter, washed with cold water, and then dried in SiO2. Products were 
purified by recrystallization using the solvent system detailed below for each compound.

\subsubsection{2-(4-Phenylthiazol-2-yl)hydrazono)ethyl)isoindoline-1,3- dione $(7 a)$}

After crystallization with water, purple crystals were obtained; yield = 59\%; M.p. $\left({ }^{\circ} \mathrm{C}\right)$ : 207-209; IR ( $\left.\mathrm{KBr}\right) 3262(\mathrm{~N}-\mathrm{H}), 3039$ $(\mathrm{C}-\mathrm{H}), 1767$ and $1712(\mathrm{C}=\mathrm{O}), 1561(\mathrm{C}=\mathrm{N}) \mathrm{cm}^{-1} \cdot{ }^{1} \mathrm{H} \quad \mathrm{NMR}$ (300 MHz, DMSO- $\left.d_{6}\right): \delta 4.44\left(\mathrm{~d}, 2 \mathrm{H}, \mathrm{CH}_{2}\right) ; 7.16(\mathrm{~s}, 1 \mathrm{H}, \mathrm{CH}$ heterocycle); 7.26 (t, 1H, CH); $7.36(\mathrm{t}, 2 \mathrm{H}, \mathrm{Ar}, 1 \mathrm{H}, \mathrm{C}-\mathrm{H}) ; 7.77$ (d, 2H, Ar); $7.91(\mathrm{~m}, 4 \mathrm{H}, \mathrm{Ar}) ; 11.88(\mathrm{~s}, 1 \mathrm{H}, \mathrm{NH}) .{ }^{13} \mathrm{C}$ NMR $\left(75.5 \mathrm{MHz}, \mathrm{DMSO}-d_{6}\right)$ : $\delta 37.4\left(\mathrm{CH}_{2}\right) ; 104.4(\mathrm{~S}-\mathrm{CH}$ heterocycle $) ; 124.2(\mathrm{CH} \mathrm{Ar}) ; 126.4(\mathrm{CH}$ Ar); 128.5 (CH Ar); 129.6 (CH Ar); 132.7 (CH Ar); 135.6 ( $\mathrm{Ar}) ; 139.1$ $(\mathrm{HC}=\mathrm{N}) ; 151.3(\mathrm{C}=\mathrm{N}) ; 168.6(\mathrm{C}=\mathrm{O}) ; 169.2(\mathrm{C}=\mathrm{O})$. Anal. Calcd. For (7a): C, 62.97; H, 3.89; N, 15.46; S, 8.85; Found: C, 62.69; H, 4.19; N, 15.68; S, 8.98. Rf: 0.625 .

\subsubsection{2-(4-Methylthiazol-2-yl)hydrazono)ethyl)isoindoline-1,3-} dione ( $7 \mathbf{b})$

After crystallization with toluene, brown crystals were obtained; yield = 55\%; M.p. $\left({ }^{\circ} \mathrm{C}\right)$ : 209-210; $\mathrm{IR}(\mathrm{KBr}) 3410(\mathrm{~N}-\mathrm{H}), 2934$ $(\mathrm{C}-\mathrm{H}), 1772$ and $1715(\mathrm{C}=\mathrm{O}), 1639(\mathrm{C}=\mathrm{N}) \mathrm{cm}^{-1}$. ${ }^{1} \mathrm{H}$ NMR $(300 \mathrm{MHz}$, DMSO-d $\left.)_{6}\right): \delta 2.08\left(\mathrm{~s}, 3 \mathrm{H}, \mathrm{CH}_{3}\right) ; 4.39\left(\mathrm{~d}, 2 \mathrm{H}, \mathrm{CH}_{2}\right) ; 6.20(\mathrm{~s}, 1 \mathrm{H}, \mathrm{CH}$ heterocycle); $7.30(\mathrm{t}, 1 \mathrm{H}, \mathrm{CH}) ; 7.84-7.92(\mathrm{~m}, 4 \mathrm{H}, \mathrm{Ar}) ; 11.51(\mathrm{~s}, 1 \mathrm{H}$, $\mathrm{NH}) .{ }^{13} \mathrm{C}$ NMR $\left(75.5 \mathrm{MHz}\right.$, DMSO- $\left.d_{6}\right): \delta 18.1\left(\mathrm{CH}_{3}\right) ; 37.4\left(\mathrm{CH}_{2}\right) ; 103.0$ (S-CH heterocycle); 124.1 (CH Ar); 132.7 (CH Ar); 135.5 (Ar); 138.9 $(\mathrm{N}-\mathrm{C}=\mathrm{C}) ; 148.3(\mathrm{HC}=\mathrm{N}) ; 155.0(\mathrm{C}=\mathrm{N}) ; 168.6(\mathrm{C}=\mathrm{O}) ; 168.9(\mathrm{C}=$ O). Anal. Calcd. For (7b): C, 55.99; H, 4.03; N, 18.65; S, 10.68; Found: C, 55.76; H, 4.37; N, 18.48; S, 10.87. Rf: 0.3.

\subsubsection{2-(4-(4-Fluorophenyl)thiazol-2-yl)hydrazono)ethyl)} isoindoline-1,3-dione (7c)

After crystallization with water, white crystals were obtained; yield $=69 \%$; M.p. $\left({ }^{\circ} \mathrm{C}\right): 214-126$; IR $(\mathrm{KBr}) 3460(\mathrm{~N}-\mathrm{H}), 3102(\mathrm{C}-\mathrm{H})$, 1772 and $1718(\mathrm{C}=\mathrm{O}), 1571(\mathrm{C}=\mathrm{N}), 1394(\mathrm{C}-\mathrm{F}) \mathrm{cm}^{-1} .{ }^{1} \mathrm{H}$ NMR $\left(300 \mathrm{MHz}, \mathrm{DMSO}-\mathrm{d}_{6}\right): \delta 4.42\left(\mathrm{~d}, 2 \mathrm{H}, \mathrm{CH}_{2}\right) ; 7.12(\mathrm{~s}, 1 \mathrm{H}, \mathrm{CH}$ heterocycle); 7.35 (t, 1H, CH); 7.77-7.82 (m, 4H, Ar); 7.85-7.94 (m, 4H, Ar); $11.88(\mathrm{~s}, 1 \mathrm{H}, \mathrm{NH}) .{ }^{13} \mathrm{C}$ NMR $\left(75.5 \mathrm{MHz}, \mathrm{DMSO}-d_{6}\right): \delta 37.4\left(\mathrm{CH}_{2}\right) ; 104.1$ (S-CH heterocycle); 116.6 (CH Ar); 124.2 ( $\mathrm{CH} \mathrm{Ar}) ; 128.4$ (CH Ar); 132.3 (CH Ar); 132.7 ( $\mathrm{Ar}) ; 135.6(\mathrm{Ar}) ; 139.3(\mathrm{C}-\mathrm{F} \mathrm{Ar}) ; 150.2(\mathrm{~N}-\mathrm{C}=$ C); $150.3(\mathrm{HC}=\mathrm{N}) ; 160.9(\mathrm{C}=\mathrm{N}) ; 168.7(\mathrm{C}=\mathrm{O}) ; 169.4(\mathrm{C}=\mathrm{O})$. Añal. Calcd. For (7c): C, 59.99; H, 3.44; N, 14.73; S, 8.43; Found: C, 60.08; H, 3.61; N, 15.01; S, 8.24. Rf: 0.625.

\subsubsection{2-(4-(4-Nitrophenyl)thiazol-2-yl)hydrazono)ethyl) isoindoline-1,3-dione (7d)}

After crystallization with water, yellow crystals were obtained; yield = 72\%; M.p. $\left({ }^{\circ} \mathrm{C}\right): 240$; IR $(\mathrm{KBr}) 3229(\mathrm{~N}-\mathrm{H}), 3110(\mathrm{C}-\mathrm{H}), 1768$ and $1705(\mathrm{C}=\mathrm{O}), 1572(\mathrm{C}=\mathrm{N}), 1510$ and $1345\left(\mathrm{NO}_{2}\right) \mathrm{cm}^{-1} \cdot{ }^{1} \mathrm{H}$ NMR (300 MHz, DMSO- $\left.d_{6}\right): \delta 4.42\left(\mathrm{~d}, 2 \mathrm{H}, \mathrm{CH}_{2}\right) ; 7.39(\mathrm{t}, 1 \mathrm{H}, \mathrm{CH}) ; 7.57(\mathrm{~s}$, $1 \mathrm{H}, \mathrm{CH}$ ); 7.86-7.98 (m, 4H, Ar); 8.05 (d, 2H, Ar); 8.22 (d, 2H, Ar); $11.96(\mathrm{~s}, 1 \mathrm{H}, \mathrm{NH}) .{ }^{13} \mathrm{C}$ NMR $\left(75.5 \mathrm{MHz}\right.$, DMSO- $\left.d_{6}\right): \delta 37.4\left(\mathrm{CH}_{2}\right) ; 108.3$ (CH heterocycle); 123.2 (CH Ar); 124.1 (CH Ar); 126.3 ( $\mathrm{CH} \mathrm{Ar}$ ); 131.7 (CH Ar); 134.6 (Ar); 140.6 (Ar); 146.1 (Ar); 150.2 (N-C=C); 154.7 $(\mathrm{HC}=\mathrm{N}) ; 160.9(\mathrm{C}=\mathrm{N}) ; 167.6(\mathrm{C}=\mathrm{O}) ; 168.8(\mathrm{C}=\mathrm{O})$. Anal. Calcd. For (7d): C, 56.01; H, 3.22; N, 17.19; S, 7.87; Found: C, 55.78; H, 3.27; N, 16.95; S, 8.15. Rf: 0.71 .

\subsubsection{2-(4-(4-Methoxyphenyl)thiazol-2-yl)hydrazono)ethyl) isoindoline-1,3-dione (7e)}

After crystallization with water, white crystals were obtained; yield = 84\%; M.p. $\left({ }^{\circ} \mathrm{C}\right): 225$; IR $(\mathrm{KBr}) 3273(\mathrm{~N}-\mathrm{H}), 3115(\mathrm{C}-\mathrm{H}), 1766$ and $1711(\mathrm{C}=\mathrm{O}), 1563(\mathrm{C}=\mathrm{N}), 1248(\mathrm{C}-\mathrm{O}) \mathrm{cm}^{-1} .{ }^{1} \mathrm{H} \mathrm{NMR}(300 \mathrm{MHz}$, DMSO- $d_{6}$ ): $\delta 3.7$ (d, 2H, $\mathrm{CH}_{2}$ ); 3.85 (s, $\left.3 \mathrm{H}, \mathrm{CH}_{3}\right) ; 7.05$ (d, 2H, $\left.\mathrm{Ar}\right) ; 7.28$ (s, $1 \mathrm{H}, \mathrm{CH}$ heterocycle); $7.50(\mathrm{t}, 1 \mathrm{H}, \mathrm{CH} 2) ; 7.55(\mathrm{~d}, 2 \mathrm{H}, \mathrm{Ar}) ; 7.85-7.88$ (m, 4H, CH Ar); 11.99 (s, 1H, NH). ${ }^{13} \mathrm{C}$ NMR (75.5 MHz, DMSO- $\left.d_{6}\right)$ : $\delta 37.4\left(\mathrm{CH}_{2}\right) ; 55.1\left(\mathrm{CH}_{3}\right) ; 101.1$ (CH heterocycle); $113.9(\mathrm{CH} \mathrm{Ar}) ; 123.1$ (CH Ar); 126.7 (CH Ar); 127.5 (CH Ar); 131.7 (Ar); 134.5 (Ar); 138.0 $(\mathrm{Ar}) ; 150.2(\mathrm{~N}-\mathrm{C}=\mathrm{C}) ; 154.1(\mathrm{HC}=\mathrm{N}) ; 158.7(\mathrm{C}=\mathrm{N}) ; 167.6(\mathrm{C}=\mathrm{O})$; $168.1(C=0)$. Anal. Calcd. For (7e): C, 61.21; H, 4.11; N, 14.28; S, 8.17; Found: C, 61.03; H, 4.28; N, 13.91; S, 7.87. Rf: 0.63.

\subsubsection{2-(4-(4-Bromophenyl)thiazol-2-yl)hydrazono)ethyl) isoindoline-1,3-dione ( $7 \boldsymbol{f})$}

After crystallization with water, white crystals were obtained; yield = 72\%; M.p. $\left({ }^{\circ} \mathrm{C}\right)$ : 190; IR ( $\left.\mathrm{KBr}\right) 3471$ and $3403(\mathrm{~N}-\mathrm{H}), 2955$ $(\mathrm{C}-\mathrm{H}), 1770$ and $1716(\mathrm{C}=\mathrm{O}), 1560(\mathrm{C}=\mathrm{N}), 719(\mathrm{C}-\mathrm{Br}) \mathrm{cm}^{-1} \cdot{ }^{1} \mathrm{H}$ NMR (300 MHz, DMSO-d d $_{6}$ : $\delta 4.40\left(\mathrm{~d}, 2 \mathrm{H}, \mathrm{CH}_{2}\right) ; 7.28(\mathrm{~s}, 1 \mathrm{H}, \mathrm{CH}$ heterocycle); $7.31(\mathrm{t}, 1 \mathrm{H}, \mathrm{CH}) ; 7.49(\mathrm{~d}, 2 \mathrm{H}, \mathrm{Ar}) ; 7.57(\mathrm{~d}, 2 \mathrm{H}, \mathrm{Ar})$; 7.85-7.94 (m, 4H, Ar); $11.73(\mathrm{~s}, 1 \mathrm{H}, \mathrm{NH}) .{ }^{13} \mathrm{C}$ NMR (75.5 MHz, DMSO$\left.d_{6}\right): \delta 37.4\left(\mathrm{CH}_{2}\right) ; 105.0(\mathrm{CH}$ heterocycle $) ; 120.0(\mathrm{C}-\mathrm{Br}) ; 123.2(\mathrm{CH}$ $\mathrm{Ar}) ; 129.7$ (CH Ar); 131.2 (CH Ar); 131.7 (CH Ar); 134.3 ( $\mathrm{Ar}) ; 134.5$ $(\mathrm{Ar}) ; 138.5(\mathrm{~N}-\mathrm{C}=\mathrm{C}) ; 155.7(\mathrm{HC}=\mathrm{N}) ; 164.4(\mathrm{C}=\mathrm{N}) ; 167.6(\mathrm{C}=\mathrm{O})$. Anal. Calcd. For (7f): C, 51.71; H, 2.97; N, 12.70; S, 7.27; Found: C, 51.42; H, 3.13; N, 12.93; S, 7.17. Rf: 0.73 .

\subsubsection{2-(4-(4-Chlorophenyl)thiazol-2-yl)hydrazono)ethyl) isoindoline-1,3-dione (7g)}

After crystallization with water, white crystals were obtained; yield = 73\%; M.p. $\left({ }^{\circ} \mathrm{C}\right)$ : 216; IR (KBr) $3465(\mathrm{~N}-\mathrm{H}), 3049(\mathrm{C}-\mathrm{H}), 1774$ and $1719(\mathrm{C}=\mathrm{O}), 1550(\mathrm{C}=\mathrm{N}), 720(\mathrm{C}-\mathrm{Cl}) \mathrm{cm}^{-1} .{ }^{1} \mathrm{H} \mathrm{NMR}(300 \mathrm{MHz}$, DMSO- $\left.d_{6}\right): \delta 4.25\left(\mathrm{~d}, 2 \mathrm{H}, \mathrm{CH}_{2}\right) ; 7.28$ ( $\mathrm{CH}$ heterocycle); $7.32(\mathrm{~d}, 2 \mathrm{H}$, Ar); 7.44 (d, 2H, Ar); 7.53 (t, 1H, CH); 7.84-7.95 (m, 4H, Ar); 11.85 (s, $1 \mathrm{H}, \mathrm{NH}) .{ }^{13} \mathrm{C}$ NMR $\left(75.5 \mathrm{MHz}\right.$, DMSO-d $\left.d_{6}\right): \delta 37.4\left(\mathrm{CH}_{2}\right) ; 104.5(\mathrm{CH}$ heterocycle); 123.1 (CH Ar); 127.1 (CH Ar); $128.5(\mathrm{CH} \mathrm{Ar}) ; 131.6(\mathrm{CH}$ $\mathrm{Ar}) ; 131.8(\mathrm{Ar}) ; 134.5(\mathrm{Ar}) ; 138.3(\mathrm{Ar}) ; 150.2(\mathrm{~N}-\mathrm{C}=\mathrm{C}) ; 155.7(\mathrm{HC}=$ $\mathrm{N}) ; 159.3(\mathrm{C}=\mathrm{N}) ; 167.5(\mathrm{C}=\mathrm{O}) ; 168.2(\mathrm{C}=\mathrm{O})$. Anal. Calcd. For $(\mathbf{7 g})$ : C, 57.50; H, 3.30; N, 14.12; S, 8.08; Found: C, 57.41; H, 3.44; N, 14.02; S, 7.88. Rf: 0.75 .

\subsubsection{2-(4-p-Tolylthiazol-2-yl)hydrazono)ethyl)isoindoline-1,3- dione ( $7 \mathbf{h})$}

After crystallization with water, white crystals were obtained; yield = 53\%; M.p. $\left({ }^{\circ} \mathrm{C}\right)$ : 209-210; IR ( KBr) $3281(\mathrm{~N}-\mathrm{H}), 3029(\mathrm{C}-\mathrm{H})$, 1775 and $1717(\mathrm{C}=\mathrm{O}), 1552(\mathrm{C}=\mathrm{N}) \mathrm{cm}^{-1} \cdot{ }^{1} \mathrm{H}$ NMR $(300 \mathrm{MHz}$, DMSO-d $\left.d_{6}\right): \delta 2.34\left(\mathrm{~s}, 3 \mathrm{H}, \mathrm{CH}_{3}\right) ; 4.13\left(\mathrm{~d}, 2 \mathrm{H}, \mathrm{CH}_{2}\right) ; 6.98(\mathrm{~s}, 1 \mathrm{H}, \mathrm{CH}$ heterocycle); $7.38(\mathrm{t}, 1 \mathrm{H}, \mathrm{CH}) ; 7.52(\mathrm{~d}, 2 \mathrm{H}, \mathrm{Ar}) ; 7.65(\mathrm{~d}, 2 \mathrm{H}, \mathrm{Ar})$; 7.87-7.92 (m, 4H, Ar); 11.80 (s, 1H, NH). ${ }^{13} \mathrm{C}$ NMR (75.5 MHz, DMSO$\left.d_{6}\right): \delta 21.3\left(\mathrm{CH}_{3}\right) ; 37.4(\mathrm{CH} 2) ; 102.8$ (CH heterocycle); $123.5(\mathrm{CH} \mathrm{Ar})$; 125.8 (CH Ar); 129.5 (CH Ar); 132.1 (CH Ar); 132.4 ( $\mathrm{Ar}) ; 134.9$ ( $\mathrm{Ar})$; $137.1(\mathrm{Ar}) ; 138.5(\mathrm{~N}-\mathrm{C}=\mathrm{C}) ; 154.7(\mathrm{HC}=\mathrm{N}) ; 151.8(\mathrm{C}=\mathrm{N}) ; 168.0(\mathrm{C}=$ O); $168.6(C=0)$. Anal. Calcd. For (7h): C, 63.81; H, 4.28; N, 14.88; S, 8.52; Found: C, 63.77; H, 4.26; N, 14.69; S, 8.29. Rf: 0.684 .

\subsection{Molecular modelling}

The structures of all compounds were obtained by applying the RM1 method [55], which is available as part of the SPARTAN'08 program [56] by using internal default settings for convergence criteria. Docking calculations and analyses were carried out using the structure of human IKB Kinase $\beta$ - IKK $\beta$ - (PDB ID code: 4KIK) as the target, which is composed of a co-crystallized complex with the inhibitor, referred as "K252A" [57]. The active site was defined as all atoms within a radius of $6.0 \AA$ from the co-crystallized ligand. The residues LEU21, THR23, LYS44, MET96, GLU97, TYR98, CYS99, ASP103, ILE165 and ASP166 were treated as flexible during the calculations. The GOLD 5.2 program [58] was used for docking calculations. Next, the Binana program [59] was used to analyse the molecular interactions present in the best docking solutions, using default settings except for the hydrogen bond distance, which was 
changed to a maximum of $3.5 \AA$. Figures were generated with Pymol [60].

\subsection{Biological in vitro evaluation}

\subsubsection{Measuring cytotoxicity against tumour cell lines by MTT assay}

The cytotoxicity of the compounds was evaluated by MTT assay against three human cancer cell lines: SF-295 (nervous system), HCT-8, (colon) and MDA/MB-435 (melanoma), all of which were obtained from the National Cancer Institute (NCI, Bethesda, MD, USA). Cell lines were maintained in RPMI 1640 medium supplemented with $10 \%$ foetal bovine serum, $2 \mathrm{mM}$ glutamine, $100 \mathrm{U} / \mathrm{mL}$ penicillin and $100 \mathrm{mg} / \mathrm{mL}$ streptomycin, at $37{ }^{\circ} \mathrm{C}$ with $5 \% \mathrm{CO} 2$. Tumour cell proliferation was quantified indirectly through the ability of living cells to reduce the yellow dye 3-(4,5-dimethyl-2thiazolyl)-2,5-diphenyl-2H-tetrazolium bromide (MTT) to form a purple formazan product [61]. Briefly, cells were plated in 96-well plates and the compounds ( $50 \mu \mathrm{g} / \mathrm{mL})$ were added to wells. After $69 \mathrm{~h}$ of incubation, the supernatant was replaced with fresh medium containing 10\% MTT. Three hours later, the MTT formazan product was dissolved in $150 \mathrm{~mL}$ DMSO, and the absorbance was measured at $595 \mathrm{~nm}$ (DTX-880, Beckman Coulter). Doxorubicin (Dox, Sigma Aldrich) was used as a positive control $(0.3 \mu \mathrm{g} / \mathrm{mL}$ ). To avoid false proliferation data, the experiments were performed in triplicate and the proliferation rate was always compared to negative controls. All replicates had similar inhibition rates, and cell proliferation rates in negative control wells were higher than those in the treated wells.

\subsubsection{Animals}

Male 4- to 6-week-old BALB/c mice were used. All mice were raised and maintained at the animal facilities of the Gonçalo Moniz Research Centre, Fundação Oswaldo Cruz, Salvador, Brazil, in rooms with controlled temperature $\left(22 \pm 2{ }^{\circ} \mathrm{C}\right)$, humidity $(55 \pm 10 \%)$ and continuous air renovation. Animals were housed in a $12 \mathrm{~h} \mathrm{light} / 12 \mathrm{~h}$ dark cycle $(6 \mathrm{am}-6 \mathrm{pm})$ and provided with rodent diet and water ad libitum. This study had prior approval by the Institutional Ethics Committee in Laboratory Animal Use.

\subsubsection{Macrophage cell cultures}

Peritoneal cells were obtained by washing, with cold Dulbecco's modified Eagle's medium (DMEM; Life Technologies, GIBCO-BRL, Gaithersburg, MD), the peritoneal cavity of mice 4-5 days after injection of $3 \%$ thioglycolate in saline ( $1.5 \mathrm{~mL}$ per mouse). Cells were washed twice with DMEM, resuspended in DMEM supplemented with $10 \%$ foetal bovine serum (Cultilab, Campinas, Brazil) and $50 \mu \mathrm{g} / \mathrm{mL}$ of gentamycin (Novafarma, Anápolis, Brazil), and plated in 96-well tissue culture plates at $2 \times 10^{5}$ cells per $0.2 \mathrm{~mL}$ per well. After $2 \mathrm{~h}$ of incubation at $37{ }^{\circ} \mathrm{C}$, non-adherent cells were removed by two washes with DMEM. Macrophages were then treated with LPS $(500 \mathrm{ng} / \mathrm{mL})$ in the absence or presence of the compounds at 1 and $10 \mu \mathrm{g} / \mathrm{mL}$. Thalidomide and dexamethasone were used as reference drugs. Cell supernatants were collected at $4 \mathrm{~h}$ of incubation to determine TNF- $\alpha$ levels or at $24 \mathrm{~h}$ of incubation to determine IL-6 levels.

\subsubsection{Lymphocyte cell culture}

Spleen cells ( $10^{5}$ cells/well) obtained from BALB/c mice were added to 96-well plates containing DMEM supplemented with $10 \%$ foetal bovine serum (Cultilab) and $50 \mu \mathrm{g} / \mathrm{mL}$ of gentamycin (Novafarma). Cells were stimulated with $1 \mu \mathrm{g} / \mathrm{mL}$ of concanavalin A (Sigma) and treated with 1 and $10 \mu \mathrm{g} / \mathrm{mL}$ of the compounds, in a final volume of $0.2 \mathrm{~mL}$. Thalidomide and dexamethasone were used as reference drugs. Cell supernatants were collected at $24 \mathrm{~h}$ of incubation to determine IFN- $\gamma$ and IL-2 levels.

\subsubsection{Cytokine determinations}

Cytokine concentrations were determined in cell-free culture supernatants using specific sandwich ELISA kits for each cytokine, following the manufacturer's instructions (Duoset, R\&D Systems, Minneapolis, MN, EUA).

\section{Acknowledgements}

We would like to thank the Brazilian National Research Council (CNPq) and the Research Foundation of Pernambuco State (FACEPE) for financial support. M.V.O.C. is recipient of a FACEPE scholarship (BFP-0107-4.03/12). A.C.L.L. is recipient of a CNPq fellowship (308806/2013-1). C.P. is grateful to FUNCAP (Fundação Cearense de Apoio ao Desenvolvimento Científico de Tecnológico). P.M.P.F. is also grateful to FAPEPI (Fundação de Amparo à Pesquisa do Estado do Piauí) for financial support. Our thanks are also due to the Department of Chemistry at the Federal University of Pernambuco (UFPE) for recording the NMR $\left({ }^{1} \mathrm{H}\right.$ and $\left.{ }^{13} \mathrm{C}\right)$, IR spectra and the elemental analysis of all compounds.

\section{Appendix A. Supplementary data}

Supplementary data related to this article can be found at http:// dx.doi.org/10.1016/j.ejmech.2015.04.041.

\section{References}

[1] H. Sano, T. Noguchi, A. Tanatani, Y. Hashimoto, H. Miyachi, Design and synthesis of subtype-selective cyclooxygenase (COX) inhibitors derived from thalidomide, Bioorg. Med. Chem. 13 (2005) 3079-3091, http://dx.doi.org/ 10.1016/j.bmc.2005.03.002.

[2] J.B. Bartlett, K. Dredge, A.G. Dalgleish, The evolution of thalidomide and its IMiD derivatives as anticancer agents, Nat. Rev. Cancer 4 (2004) 314-322, http://dx.doi.org/10.1038/nrc1323.

[3] J.A. Keifer, D.C. Guttridge, B.P. Ashburner, A.S. Baldwin, Inhibition of NF-kappa B activity by thalidomide through suppression of IkappaB kinase activity, J. Biol. Chem. 276 (2001) 22382-22387, http://dx.doi.org/10.1074/ jbc.M100938200.

[4] E.J.C. de-Blanco, B. Pandit, Z. Hu, J. Shi, A. Lewis, P.-K. Li, Inhibitors of NFkappaB derived from thalidomide, Bioorg. Med. Chem. Lett. 17 (2007) 6031-6035, http://dx.doi.org/10.1016/j.bmcl.2007.01.088.

[5] J.A. Keifer, D.C. Guttridge, P. Brian, A.S. Baldwin, B.P. Ashburner, Inhibition of NF- $\kappa$ B activity by thalidomide through suppression of I $\kappa$ B kinase activity, J. Biol. Chem. 276 (2001) 22382-22387, http://dx.doi.org/10.1074/ jbc.M100938200.

[6] T. Yagyu, H. Kobayashi, H. Matsuzaki, K. Wakahara, T. Kondo, N. Kurita, et al., Thalidomide inhibits tumor necrosis factor-alpha-induced interleukin-8 expression in endometriotic stromal cells, possibly through suppression of nuclear factor-kappaB activation, J. Clin. Endocrinol. Metab. 90 (2005) 3017-3021, http://dx.doi.org/10.1210/jc.2004-1946.

[7] S. Majumdar, B. Lamothe, B.B. Aggarwal, Thalidomide suppresses NF-B activation induced by TNF and $\mathrm{H}_{2} \mathrm{O}_{2}$, but not that activated by ceramide, lipopolysaccharides, or phorbol ester, J. Immunol. 168 (2002) 2644-2651, http:// dx.doi.org/10.4049/jimmunol.168.6.2644.

[8] J. Zhang, P.L. Yang, N.S. Gray, Targeting cancer with small molecule kinase inhibitors, Nat. Rev. Cancer 9 (2009) 28-39, http://dx.doi.org/10.1038/ nrc2559.

[9] J. Kempson, S.H. Spergel, J. Guo, C. Quesnelle, P. Gill, D. Belanger, et al., Novel tricyclic inhibitors of IkappaB kinase, J. Med. Chem. 52 (2009) 1994-2005, http://dx.doi.org/10.1021/jm8015816.

[10] A. Chanan-Khan, K.C. Miller, L. Musial, D. Lawrence, S. Padmanabhan, K. Takeshita, et al., Clinical efficacy of lenalidomide in patients with relapsed or refractory chronic lymphocytic leukemia: results of a phase II study, J. Clin. Oncol. 24 (2006) 5343-5349, http://dx.doi.org/10.1200/JCO.2005.05.0401.

[11] F. van Rhee, M. Dhodapkar, J.D. Shaughnessy, E. Anaissie, D. Siegel, A. Hoering et al., First thalidomide clinical trial in multiple myeloma: a decade, Blood 112 (2008) 1035-1038, http://dx.doi.org/10.1182/blood-2008-02-140954.

[12] H. Quach, D. Ritchie, A.K. Stewart, P. Neeson, S. Harrison, M.J. Smyth, et al., Mechanism of action of immunomodulatory drugs (IMiDS) in multiple myeloma, Leukemia 24 (2010) 22-32, http://dx.doi.org/10.1038/ leu.2009.236.

[13] Y. Hashimoto, Thalidomide as a multi-template for development of biologically active compounds, Arch. Pharm. (Weinheim) 341 (2008) 536-547, http://dx.doi.org/10.1002/ardp.200700217.

[14] A.L. Machado, L.M. Lima, J.X. Araújo, C.A.M. Fraga, V.L.G. Koatz, E.J. Barreiro, Design, synthesis and antiinflammatory activity of novel phthalimide 
derivatives, structurally related to thalidomide, Bioorg. Med. Chem. Lett. 15 (2005) 1169-1172, http://dx.doi.org/10.1016/j.bmcl.2004.12.012.

[15] S. Inatsuki, T. Noguchi, H. Miyachi, S. Oda, T. Iguchi, M. Kizaki, et al., Tubulinpolymerization inhibitors derived from thalidomide, Bioorg. Med. Chem. Lett. 15 (2005) 321-325, http://dx.doi.org/10.1016/j.bmcl.2004.10.072.

[16] X.-B. Meng, D. Han, S.-N. Zhang, W. Guo, J.-R. Cui, Z.-J. Li, Synthesis and antiinflammatory activity of N-phthalimidomethyl 2,3-dideoxy- and 2,3unsaturated glycosides, Carbohydr. Res. 342 (2007) 1169-1174, http:// dx.doi.org/10.1016/j.carres.2007.03.009.

[17] M.V. de Almeida, F.M. Teixeira, M.V.N. de Souza, G.W. Amarante, C.C.de S. Alves, S.H. Cardoso, et al., Thalidomide analogs from diamines: synthesis and evaluation as inhibitors of TNF-alpha production, Chem. Pharm. Bull. (Tokyo) 55 (2007) 223-226, http://dx.doi.org/10.1248/cpb.55.223.

[18] S.G. Stewart, D. Spagnolo, M.E. Polomska, M. Sin, M. Karimi, L.J. Abraham, Synthesis and TNF expression inhibitory properties of new thalidomide analogues derived via Heck cross coupling, Bioorg. Med. Chem. Lett. 17 (2007) 5819-5824, http://dx.doi.org/10.1016/j.bmcl.2007.08.042.

[19] H.-W. Man, P. Schafer, L.M. Wong, R.T. Patterson, L.G. Corral, H. Raymon, et al., Discovery of (S)-N-[2-[1-(3-ethoxy-4-methoxyphenyl)-2methanesulfonylethyll-1,3-dioxo-2,3-dihydro-1H-isoindol-4-yl] acetamide (apremilast), a potent and orally active phosphodiesterase 4 and tumor necrosis factor-alpha inhibitor, J. Med. Chem. 52 (2009) 1522-1524, http:/ dx.doi.org/10.1021/jm900210d.

[20] S.M. Capitosti, T.P. Hansen, M.L. Brown, Thalidomide analogues demonstrate dual inhibition of both angiogenesis and prostate cancer, Bioorg. Med. Chem. 12 (2004) 327-336, http://dx.doi.org/10.1016/j.bmc.2003.11.007.

[21] H. Sano, T. Noguchi, A. Miyajima, Y. Hashimoto, H. Miyachi, Anti-angiogenic activity of basic-type, selective cyclooxygenase (COX)-1 inhibitors, Bioorg. Med. Chem. Lett. 16 (2006) 3068-3072, http://dx.doi.org/10.1016 j.bmcl.2006.02.021.

[22] T. Noguchi, H. Fujimoto, H. Sano, A. Miyajima, H. Miyachi, Y. Hashimoto Angiogenesis inhibitors derived from thalidomide, Bioorg. Med. Chem. Lett. 15 (2005) 5509-5513, http://dx.doi.org/10.1016/j.bmcl.2005.08.086.

[23] M.A.-H. Zahran, T.A.-R. Salem, R.M. Samaka, H.S. Agwa, A.R. Awad, Design, synthesis and antitumor evaluation of novel thalidomide dithiocarbamate and dithioate analogs against Ehrlich ascites carcinoma-induced solid tumor in Swiss albino mice, Bioorg. Med. Chem. 16 (2008) 9708-9718, http:// dx.doi.org/10.1016/j.bmc.2008.09.071.

[24] S.H.L. Kok, R. Gambari, C.H. Chui, M.C.W. Yuen, E. Lin, R.S.M. Wong, et al., Synthesis and anti-cancer activity of benzothiazole containing phthalimide on human carcinoma cell lines, Bioorg. Med. Chem. 16 (2008) 3626-3631, http:// dx.doi.org/10.1016/j.bmc.2008.02.005.

[25] S.H. Chan, K.H. Lam, C.H. Chui, R. Gambari, M.C.W. Yuen, R.S.M. Wong, et al., The preparation and in vitro antiproliferative activity of phthalimide based ketones on MDAMB-231 and SKHep-1 human carcinoma cell lines, Eur. J. Med. Chem. 44 (2009) 2736-2740, http://dx.doi.org/10.1016/ j.ejmech.2008.10.024

[26] S.M. Sondhi, R. Rani, P. Roy, S.K. Agrawal, A.K. Saxena, Microwave-assisted synthesis of N-substituted cyclic imides and their evaluation for anticancer and anti-inflammatory activities, Bioorg. Med. Chem. Lett. 19 (2009) 1534-1538, http://dx.doi.org/10.1016/j.bmcl.2008.07.048.

[27] M. Campbell, Transition metal complexes of thiosemicarbazide and thiosemicarbazones, Coord. Chem. Rev. 15 (1975) 279-319, http://dx.doi.org/ 10.1016/S0010-8545(00)80276-3.

[28] S. Padhyé, G.B. Kauffman, Transition metal complexes of semicarbazones and thiosemicarbazones, Coord. Chem. Rev. 63 (1985) 127-160, http://dx.doi.org/ 10.1016/0010-8545(85)80022-9.

[29] I. Haiduc, C. Silvestru, Metal compounds in cancer chemotherapy, Coord. Chem. Rev. 99 (1990) 253-296, http://dx.doi.org/10.1016/0010-8545(85) 80022-9.

[30] X.W. Douglas, S.B. Padhye, P.B. Sonawane, D. West, Structural and Physical Correlations in the Biological Properties of Transition Metal Heterocyclic Thiosemicarbazone and S-alkyldithiocarbazate Complexes, Springer Berlin Heidelberg, Berlin, Heidelberg, 1991, http://dx.doi.org/10.1007/3-540-534997 .1.

[31] A.I. Matesanz, P. Souza, $\alpha-\mathrm{N}$-heterocyclic thiosemicarbazone derivatives as potential antitumor agents: a structure-activity relationships approach, Mini Rev. Med. Chem. 9 (2009) 1389-1396, http://dx.doi.org/10.2174 138955709789957422

[32] C. Pessoa, P.M.P. Ferreira, L.V.C. Lotufo, M.O. de Moraes, S.M.T. Cavalcanti, L.C.D. Coêlho, et al., Discovery of phthalimides as immunomodulatory and antitumor drug prototypes, ChemMedChem 5 (2010) 523-528, http:/ dx.doi.org/10.1002/cmdc.200900525.

[33] S. Bondock, W. Khalifa, A.A. Fadda, Synthesis and antimicrobial evaluation of some new thiazole, thiazolidinone and thiazoline derivatives starting from 1 chloro-3,4-dihydronaphthalene-2-carboxaldehyde, Eur. J. Med. Chem. 42 (2007) 948-954, http://dx.doi.org/10.1016/j.ejmech.2006.12.025.

[34] B.V Nonius, Enraf-Nonius COLLECT, (n.d.)

[35] Z. Otwinowski, W. Minor, Methods in enzymology, Macromol. Crystallogr. Part A 276 (1997) 307-326, http://dx.doi.org/10.1016/S0076-6879(97)76066-X.

[36] G. Sheldrick, SHELXL-97 and SHELXS-97, Program for X-ray Crystal Structure
Solution and Refinement, Univ. Göttingen, 1997. http://scholar.google.com.br/ scholar?q=SHELXS-97. Program for Crystal Structure Resolution\#3 (accessed 13.11.12.)

[37] L.J. Farrugia, ORTEP-3 for windows - a version of ORTEP-III with a Graphical User Interface (GUI), J. Appl. Crystallogr. 30 (1997) 565, http://dx.doi.org/ 10.1107/S0021889897003117.

[38] L.J. Farrugia, WinGX suite for small-molecule single-crystal crystallography, J. Appl. Crystallogr. 32 (1999) 837-838, http://dx.doi.org/10.1107/ S0021889899006020.

[39] F.H. Allen, O. Kennard, D.G. Watson, L. Brammer, A.G. Orpen, R. Taylor, Tables of bond lengths determined by X-ray and neutron diffraction. Part 1 . Bond lengths in organic compounds, J. Chem. Soc. Perkin Trans. 2 (1987) S1, http://dx.doi.org/10.1039/p298700000s1.

[40] V. Kindler, A.P. Sappino, G.E. Grau, P.F. Piguet, P. Vassalli, The inducing role of tumor necrosis factor in the development of bactericidal granulomas during BCG infection, Cell 56 (1989) 731-740, http://dx.doi.org/10.1016/00928674(89)90676-4.

[41] J.L. Flynn, M.M. Goldstein, J. Chan, K.J. Triebold, K. Pfeffer, C.J. Lowenstein, et al., Tumor necrosis factor-alpha is required in the protective immune response against Mycobacterium tuberculosis in mice, Immunity 2 (1995) 561-572, 1074-7613(95)90001-2.

[42] K.J. Tracey, A. Cerami, Tumor necrosis factor and regulation of metabolism in infection: role of systemic versus tissue levels, Proc. Soc. Exp. Biol. Med. 200 (1992) 233-239. http://www.ncbi.nlm.nih.gov/pubmed/1579588.

[43] J.M. Tramontana, U. Utaipat, A. Molloy, P. Akarasewi, M. Burroughs, S. Makonkawkeyoon, et al., Thalidomide Treatment Reduces Tumor Necrosis Factor Alpha Production and Enhances Weight Gain in Patients with Pulmonary Tuberculosis, 1995. http://www.pubmedcentral.nih.gov/articlerender. fcgi? artid $=2229989 \&$ tool $=$ pmcentrez\&rendertype $=$ abstract.

[44] E.P. Sampaio, G. Kaplan, A. Miranda, J.A. Nery, C.P. Miguel, S.M. Viana, et al., The influence of thalidomide on the clinical and immunologic manifestation of erythema nodosum leprosum, J. Infect. Dis. 168 (1993) 408-414. http:// www.ncbi.nlm.nih.gov/pubmed/8335978.

[45] L. Tsenova, K. Sokol, V.H. Freedman, G. Kaplan, A combination of thalidomide plus antibiotics protects rabbits from mycobacterial meningitis-associated death, J. Infect. Dis. 177 (1998) 1563-1572. http://www.ncbi.nlm.nih.gov/ pubmed/9607834.

[46] K.A. Smith, Interleukin-2: inception, impact, and implications, Science 240 (1988) 1169-1176, http://dx.doi.org/10.1126/science.3131876.

[47] M.A. Farrar, R.D. Schreiber, The molecular cell biology of interferon-gamma and its receptor, Annu. Rev. Immunol. 11 (1993) 571-611, http://dx.doi.org/ 10.1146/annurev.iy.11.040193.003035.

[48] U. Boehm, T. Klamp, M. Groot, J.C. Howard, Cellular responses to interferongamma, Annu. Rev. Immunol. 15 (1997) 749-795, http://dx.doi.org/10.1146/ annurev.immunol.15.1.749.

[49] M. DuPage, C. Mazumdar, L.M. Schmidt, A.F. Cheung, T. Jacks, Expression of tumour-specific antigens underlies cancer immunoediting, Nature 482 (2012) 405-409, http://dx.doi.org/10.1038/nature10803.

[50] V. Shankaran, H. Ikeda, A.T. Bruce, J.M. White, P.E. Swanson, L.J. Old, et al., IFNgamma and lymphocytes prevent primary tumour development and shape tumour immunogenicity, Nature 410 (2001) 1107-1111, http://dx.doi.org/ $10.1038 / 35074122$

[51] T. van der Poll, C.V. Keogh, X. Guirao, W.A. Buurman, M. Kopf, S.F. Lowry, Interleukin-6 gene-deficient mice show impaired defense against pneumococcal pneumonia, J. Infect. Dis. 176 (1997) 439-444, http://dx.doi.org/ $10.1086 / 514062$.

[52] C.-H. Leung, D.S.-H. Chan, Y.-W. Li, W.-F. Fong, D.-L. Ma, Hit identification of IKK $\beta$ natural product inhibitor, BMC Pharmacol. Toxicol. 14 (2013) 3, http:// dx.doi.org/10.1186/2050-6511-14-3.

[53] M. Karin, Y. Yamamoto, Q.M. Wang, The IKK NF-kappa B system: a treasure trove for drug development, Nat. Rev. Drug Discov. 3 (2004) 17-26, http:// dx.doi.org/10.1038/nrd1279.

[54] O. Korb, T. Stützle, T.E. Exner, Empirical scoring functions for advanced protein-ligand docking with PLANTS, J. Chem. Inf. Model 49 (2009) 84-96, http://dx.doi.org/10.1021/ci800298z.

[55] G.B. Rocha, R.O. Freire, A.M. Simas, J.J.P. Stewart, RM1: a reparameterization of AM1 for H, C, N, O, P, S, F, Cl, Br, and I, J. Comput. Chem. 27 (2006) 1101-1111, http://dx.doi.org/10.1002/jcc.20425.

[56] Spartan'08 Tutorial and User's Guide: Wavefunction, 2008. http://www. wavefun.com/products/spartan.html.

[57] S. Liu, Y.R. Misquitta, A. Olland, M.A. Johnson, K.S. Kelleher, R. Kriz, et al., Crystal structure of a human IкB kinase $\beta$ asymmetric dimer, J. Biol. Chem. 288 (2013) 22758-22767, http://dx.doi.org/10.1074/jbc.M113.482596.

[58] Gold software. http://www.ccdc.cam.ac.uk.

[59] J.D. Durrant, J.A. McCammon, BINANA: a novel algorithm for ligand-binding characterization, J. Mol. Graph. Model 29 (2011) 888-893, http://dx.doi.org/ 10.1016/j.jmgm.2011.01.004.

[60] The PyMOL Molecular Graphics System, Version 1.3 Schrödinger, LLC., (n.d.).

[61] T. Mosmann, Rapid colorimetric assay for cellular growth and survival: application to proliferation and cytotoxicity assays, J. Immunol. Methods 65 (1983) 55-63, http://dx.doi.org/10.1016/0022-1759(83)90303-4. 